\title{
Synchronizing terrestrial and marine records of environmental change across the Eocene-
}

\section{Oligocene transition}

Diana Sahy ${ }^{1,2,{ }^{*}}$, Daniel J. Condon ${ }^{1}$, Dennis O. Terry Jr. ${ }^{3}$, Anne U. Fischer ${ }^{4}$, Klaudia F. Kuiper ${ }^{4,5}$

${ }^{1}$ British Geological Survey, Keyworth, NG12 5GG, United Kingdom, dihy@bgs.ac.uk, dcondon@bgs.ac.uk

${ }^{2}$ Department of Geology, University of Leicester, University Road, Leicester, LE1 7RH, United Kingdom

${ }^{3}$ Earth and Environmental Science, Temple University, Philadelphia, PA 19122, USA, doterry@temple.edu

${ }^{4}$ Faculty of Earth and Life Sciences, Vrije Universiteit, 1085 De Boelelaan, Amsterdam, $1081 \mathrm{HV}$, The

Netherlands, anne.fischer@falw.vu.nl, k.f.kuiper@vu.nl

${ }^{5}$ Department of Earth Sciences, Utrecht University, Budapestlaan 17, Utrecht, 3584 CD, The Netherlands

* Corresponding author, Tel: +44 1159363278

\section{Abstract}

Records of terrestrial environmental change indicate that continental cooling and/or aridification may have predated the greenhouse-icehouse climate shift at the Eocene-Oligocene transition (EOT) by ca. 600 kyr. In North America, marine-terrestrial environmental change asychronicity is inferred from a direct comparison between the astronomically tuned marine EOT record, and published ${ }^{40} \mathrm{Ar} /{ }^{39} \mathrm{Ar}$ geochronology of volcanic tuffs from the White River Group (WRG) sampled at Flagstaff Rim (Wyoming) and Toadstool Geologic Park (Nebraska), which are type sections for the Chadronian and Orellan North American Land Mammal Ages. We present a new age-model for the WRG, underpinned by high-precision ${ }^{206} \mathrm{~Pb} /{ }^{238} \mathrm{U}$ zircon dates from 15 volcanic tuffs, including six tuffs previously dated using the ${ }^{40} \mathrm{Ar} /{ }^{39} \mathrm{Ar}$ technique. Weighted mean zircon ${ }^{206} \mathrm{~Pb} /{ }^{238} \mathrm{U}$ dates from this study are up to $1.0 \mathrm{Myr}$ younger than published anorthoclase and biotite ${ }^{40} \mathrm{Ar} /{ }^{39} \mathrm{Ar}$ data (calibrated relative to Fish Canyon sanidine at 28.201 Ma). Giving consideration to the complexities, strengths, and limitations associated with both the ${ }^{40} \mathrm{Ar} /{ }^{39} \mathrm{Ar}$ and ${ }^{206} \mathrm{~Pb} /{ }^{238} \mathrm{U}$ datasets, our interpretation is that the recalculated ${ }^{40} \mathrm{Ar} /{ }^{39} \mathrm{Ar}$ dates are anomalously old, and the ${ }^{206} \mathrm{~Pb} /{ }^{238} \mathrm{U}$ (zircon) dates more accurately constrain deposition. ${ }^{206} \mathrm{~Pb} /{ }^{238} \mathrm{U}$ calibrated age-depth models were developed in order to 
facilitate a robust intercomparison between marine and terrestrial archives of environmental change, and indicate that: (i) early Orellan (terrestrial) cooling recorded at Toadstool Geologic Park was synchronous with the onset of early Oligocene Antarctic glaciation and (ii) the last appearance datums of key Chadronian mammal taxa are diachronous by ca. 0.7 Myr between central Wyoming and NW Nebraska.

Keywords: U-Pb; zircon; geochronology; NALMA; Eocene-Oligocene transition; White River Group

\section{Highlights}

- U-Pb dated White River tuffs are ca. 0.6 Myr younger than published ${ }^{40} \mathrm{Ar} /{ }^{39} \mathrm{Ar}$ data

- Terrestrial climate shift across the EOT coincides with Antarctic glaciation

- Mammal first and last occurrence events are diachronous by 0.7 Myr over $400 \mathrm{~km}$

- Tuning of the Oligocene time scale to the 405 kyr eccentricity signal is correct

\section{Introduction}

During the Eocene-Oligocene transition (EOT, 34.0-33.5 Ma) the Earth's climate shifted abruptly from greenhouse to icehouse mode, resulting in the development of a continent-scale Antarctic icesheet (Ivany et al., 2006; Shackleton and Kennett, 1975; Zachos et al., 2001). Marine records of the EOT are characterized by a stepwise $1.2-1.5 \%$ positive shift in benthic foraminiferal $\delta^{18} \mathrm{O}$ values, which took place over ca. 400 kyr, and was synchronous across ocean basins (Cramer et al., 2009; Coxall et al., 2005; Pälike et al., 2006; Pearson et al., 2008; Zachos et al., 1996). The timing of events surrounding the marine EOT is established by the astronomical tuning of the ODP Site 1218 record from the equatorial Pacific (Pälike et al., 2006; hereafter ATPS06), which provided continuous coverage between chrons $\mathrm{C} 1 \mathrm{n}-\mathrm{C} 19 \mathrm{n}(0-41.5 \mathrm{Myr})$. The detailed pattern of the $\delta^{18} \mathrm{O}$ shift varies between localities and is dependent on stratigraphic completeness and sampling resolution, but two major events are widely recognised: (i) a precursor event (EOT-1) marked by a ca. $0.5 \%$ o $\delta^{18} \mathrm{O}$ 
increase around 34.0-33.8 Myr associated with $>2{ }^{\circ} \mathrm{C}$ decrease in sea-surface temperatures, and (ii) a ca. $1.0 \% \delta^{18} \mathrm{O}$ positive shift (Oi-1 event) at $33.6 \mathrm{Myr}$, close to the base of magnetochron $\mathrm{C} 13 \mathrm{n}$, related to further cooling and Antarctic ice-sheet expansion (Coxall et al., 2005; Katz et al., 2008; Wade et al., 2012). Coeval terrestrial records from the Americas, Europe, and Asia exhibit a wide range of responses to marine cooling and Antarctic ice-sheet growth, from relative climatic stability (Grimes et al., 2005; Kohn et al., 2004; Retallack et al., 2004) to a $>4{ }^{\circ} \mathrm{C}$ drop in mean annual temperature (MAT) (Hren et al., 2013; Wolfe, 1994; Zanazzi et al., 2007; Zanazzi et al., 2009), and a shift towards more arid conditions (Boardman and Secord, 2013; Dupont-Nivet et al., 2007; Xiao et al., 2010; Zhang and Guo, 2014). Where significant environmental changes are present in the terrestrial record, their timing relative to the marine EOT is established based on magnetostratigraphy, (e.g. Hren et al., 2013; Dupont-Nivet et al., 2007) and to a lesser extent ${ }^{40} \mathrm{Ar} /{ }^{39} \mathrm{Ar}$ dating of volcanic tuffs (e.g. Boardman and Secord, 2013; Zanazzi et al., 2007; Zanazzi et al., 2009) and floating astronomical time scales (Xiao et al., 2010). Combined, these studies indicate that although terrestrial environmental change broadly coincided with the EOT-1 and Oi-1 interval at some localities (Hren et al., 2013; Xiao et al., 2010), at others it apparently predates changes associated with the marine EOT by 100-600 kyr (Boardmann and Secord, 2013; Zanazzi et al., 2007; Zanazzi et al., 2009; Zhang and Guo, 2014).

Extensive radio-isotopic dating of the terrestrial EOT has so far only been carried out on volcanic tuffs intercalated in the White River Group (WRG) in North America (Obradovich et al., 1995; Swisher and Prothero, 1990). The predominantly fluvial and eolian deposits of the WRG host one of the richest known late Eocene-Oligocene mammal fossil assemblages, which form the basis for the definition of the Chadronian, Orellan and Whitneyan North American Land Mammal Ages (NALMA) (Prothero and Emry, 1996; Prothero and Whittlesey, 1998; Wood et al., 1941). The ChadronianOrellan boundary is considered broadly equivalent to the EOT (Prothero and Swisher, 1992; Swisher and Prothero, 1990). Stable isotope analyses of fossil mammal teeth and bones from Toadstool Geologic Park (hereafter TGP), a key WRG locality in NW Nebraska (Figure 1.A), shows a 1.0-1.5 \%o 
increase in mean $\delta^{18} \mathrm{O}$ across the Chadronian-Orellan transition, interpreted as $7.1 \pm 3.1^{\circ} \mathrm{C}$ drop in MAT (Zanazzi et al., 2007; Zanazzi et al., 2009). A ca. $8^{\circ} \mathrm{C}$ drop in MAT is also supported by regional paleobotanical studies from western North America (Wolfe, 1994) across this interval. However, in an alternative interpretation of the TGP stable isotope record, Boardman and Secord (2013) attributed the Chadronian-Orellan shift in tooth enamel $\delta^{18} \mathrm{O}$ to increased aridity, resulting in a decline of wet habitats and a proliferation of less water-dependent mammals, rather than cooling.

The accuracy of published ${ }^{40} \mathrm{Ar} /{ }^{39} \mathrm{Ar}$ data from the WRG, and the TGP record itself (Obradovich et al., 1995; Swisher and Prothero 1990), is a critical factor in the correlation of environmental change in North America to the marine EOT. The accuracy of ${ }^{40} \mathrm{Ar} /{ }^{39} \mathrm{Ar}$ dates is controlled by the accuracy of the ${ }^{40} \mathrm{~K}$ decay constant, the assigned age of the mineral standard used (usually Fish Canyon sanidine, hereafter FCs), and the nature and complexity of the analysed material. ${ }^{40} \mathrm{Ar} /{ }^{39} \mathrm{Ar}$ dates from the WRG were reported relative to an FCs age of $27.84 \mathrm{Ma}$ (Swisher and Prothero, 1990), and the ${ }^{40} \mathrm{~K}$ decay constant recommended by Steiger and Jäger (1977). Over the last two decades the age of FCs has been the topic of ongoing revisions, through calibration relative to primary K-Ar standards, astronomically dated tuffs, and the U-Pb system. Recent results converge towards a FCs age of ca. 28.20 Ma with an uncertainty of less than 0.1 Myr (Kuiper et al., 2008; Renne et al., 1994; Renne et al., 2010; Renne et al., 1998; Rivera et al., 2011; Wotzlaw et al., 2013). The ${ }^{40} \mathrm{~K}$ decay constant has also been revised through intercalibration and statistical optimization of the ${ }^{40} \mathrm{Ar} /{ }^{39} \mathrm{Ar}$ and $\mathrm{U}-\mathrm{Pb}$ systems (Min et al., 2000; Renne et al., 2010).

Recalculation of published ${ }^{40} \mathrm{Ar} /{ }^{39} \mathrm{Ar}$ data from the WRG (Swisher and Prothero, 1990) relative to a FCs age of $28.201 \pm 0.046 \mathrm{Ma}$ (Kuiper et al., 2008) and a ${ }^{40} \mathrm{~K}$ decay constant value of $5.37 \times 10^{-10} / \mathrm{yr}$ (Min et al., 2000), both adopted in the 2012 edition of the Geological Time Scale (GTS12) (Gradstein et al., 2012), results in a $1.28 \%$, or ca. 450 kyr increase in numerical age. This increase exceeds the typical age uncertainty quoted for the WRG tuffs, which is on the order of \pm 0.1-0.2 Myr (all uncertainties are $2 \sigma$ unless otherwise stated), and has a significant impact on the age of events 
recorded in the WRG when considered relative to the marine EOT chronology based on ATPSO6. Recalculated ${ }^{40} \mathrm{Ar} /{ }^{39} \mathrm{Ar}$ dates from tuffs found within magnetochrons $\mathrm{C} 16 \mathrm{n} .1 \mathrm{n}-\mathrm{C} 12 \mathrm{n}$, (Prothero, 1996; Prothero and Swisher, 1992) are up to 600 kyr older than expected based on the ATPS06. Additionally, calibration of the TGP stable isotope record (Boardman and Secord, 2013; Zanazzi et al., 2007; Zanazzi et al., 2009) relative to these recalculated ${ }^{40} \mathrm{Ar} /{ }^{39} \mathrm{Ar}$ dates suggests that the Chadronian-Orellan $\delta^{18} \mathrm{O}$ shift predates cooling in the marine realm by ca. $600 \mathrm{kyr}$. The possible causes of these discrepancies include potential inaccuracies in the ${ }^{40} \mathrm{Ar} /{ }^{39} \mathrm{Ar}$ dataset, errors in the magnetic polarity pattern of the WRG, and/or inaccuracy of the ATPSO6. However, if both the recalculated ${ }^{40} \mathrm{Ar} /{ }^{39} \mathrm{Ar}$ dates from the WRG, and the ATPSO6 are accurate, the implication is that cooling and/or aridification in central North America was offset from the early Oligocene Antarctic glaciation.

Published mineralogical data (Larson and Evanoff, 1998) and a pilot study of tuffs from E Wyoming (Scott et al., 1999) point towards high-precision U-Pb dating of zircon as a viable alternative for refining the numerical age calibration of the WRG record. The accuracy of $\mathrm{U} / \mathrm{Pb}$ zircon data is controlled by the accuracy of the ${ }^{238} \mathrm{U}$ decay constant, determined through alpha counting experiments (Jaffey et al., 1971), and the gravimetric calibration of isotopic tracer solutions which is traceable to SI units (Condon et al., 2015; McLean et al., 2015). As such there is a potential to produce ${ }^{206} \mathrm{~Pb} /{ }^{238} \mathrm{U}$ (zircon) based radio-isotopic ages with total uncertainties of ca. $0.12 \%$ which have a resolving power (i.e., precision which does not include systematic sources of uncertainty) on the order of $0.05 \%$. When coupled with the availability of multiple closely spaced tuffs, the high resolving power of the method allows for the assessment of complex zircon populations, and the accurate identification of analyses affected by pre-, and post-eruptive bias, resulting in robust eruption ages.

In this paper we present high-precision ${ }^{206} \mathrm{~Pb} /{ }^{238} \mathrm{U}$ chemical abrasion isotope dilution thermal ionization mass spectrometry (CA-ID-TIMS) zircon dates for 15 WRG tuffs from central Wyoming and 
NW Nebraska (Figure 1), six of which have been previously dated using the ${ }^{40} \mathrm{Ar} /{ }^{39} \mathrm{Ar}$ technique (Obradovich et al., 1995; Swisher and Prothero, 1990). These dates provide an improved age model for the deposition of the WRG, and are used to (i) assess whether environmental and faunal change across the EOT in North America was offset from, or coincident with, and possibly related to, changes in the marine realm, and (ii) to improve the numerical age calibration of the ChadronianWhitneyan NALMAs.

\section{Geological setting of the WRG}

The WRG succession comprises fluvial and eolian deposits that accummulated in the North American midcontinent (Figure 1.A) and adjacent Rocky Mountain basins during the late Eocene and early Oligocene (ca. 37-29 Myr). Deposits consist of fine-grained reworked volcanic sediments and, to a lesser extent, siliciclastic material derived from the Hartville, Laramie and Black Hills uplifts (Clark, 1975; Stanley and Benson, 1979), interspaced with primary air-fall tuffs. The volcanic material was sourced from explosive volcanism in Nevada and Utah (Larson and Evanoff, 1998), ca. 500-800 km south-west of the main WRG outcrops. As a result, both the thickness of individual stratigraphic units within the WRG, and the grainsize of primary volcanic tuffs decrese from south-west to northeast, as distance from the source area increases (Emry et al., 1987). The lithostratigraphic nomenclature varies between localities (LaGarry, 1998; Terry, 1998; Terry and LaGarry, 1998), with White River deposits ranked as a group in Nebraska and South Dakota and as a formation in Wyoming. Volcanic tuff samples for this study were collected from two localities: Flagstaff Rim in Wyoming, and TGP in Nebraska.

\subsection{Flagstaff Rim}

The Flagstaff Rim section is situated in central Wyoming, ca. $20 \mathrm{~km}$ southwest of Casper (Figure 1.A). The White River Formation, exposed in a $200 \mathrm{~m}$ high cliff and smaller surrounding outcrops, overlies 
the Cretaceous Cody Shale, and is in turn unconformably overlain by the Miocene Split Rock Formation (Emry, 1973). The White River Formation at this locality consists mainly of volcaniclastic overbank siltstones, interbedded with tabular and lenticular channel sandstones. 17 volcanic tuffs have been identified at Flagstaff Rim (Figure 1.B), the most prominent of which are labelled A to J (Emry, 1973). Mammal assemblages from the lower part of the section, up to $15 \mathrm{~m}$ below the B tuff, indicate a late early Chadronian age, while the interval from $15 \mathrm{~m}$ below the $B$ tuff to $15 \mathrm{~m}$ above the $\mathrm{G}$ tuff has been designated as the type section for the middle Chadronian (Prothero and Emry, 1996; Prothero and Emry, 2004). The presence of brontotheres up to the level of the J tuff indicates that the top of the Flagstaff Rim succession is of late Chadronian age (Emry, 1992). According to existing literature, the section spans magnetochrons C16n.1n-C15n (Prothero and Swisher, 1992). Estimates of the time interval represented at Flagstaff Rim vary from 0.6 Myr based on magnetostratigraphic correlation to ATPS06, to ca. 1 Myr based on sanidine ${ }^{40} \mathrm{Ar} /{ }^{39} \mathrm{Ar}$ dates from the B and J tuffs (Obradovich et al., 1995), and ca. 1.5 Myr based on biotite and anorthoclase ${ }^{40} \mathrm{Ar} /{ }^{39} \mathrm{Ar}$ dates from the B, F, G, I, and J tuffs (Swisher and Prothero, 1990).

\subsection{Toadstool Geological Park}

TGP is situated in nortwestern Nebraska, ca. $20 \mathrm{~km}$ west of Chadron (Figure 1.A), and consists of a series of laterally continous outcrops spread over ca. $6 \mathrm{~km}^{2}$ along Big Cottonwood Creek. Lithostratigraphically the TGP succession comprises the Chadron and Brule Formations of the WRG (Figure 1.C). The Chadron Formation is further subdivided into the Peanut Peak Member, consisting of bluish green, gray, and olive claystones (Terry, 1998), and the overlying Big Cottonwood Creek Member which comprises primarily volcaniclastic overbank silty claystones, interbedded with tabular and lenticular channel sandstones (Terry and LaGarry, 1998). The Brule Formation is subdivided into the Orella, Whitney, and Brown Siltstone Members. The Orella Member consists of thinly interbedded brown and brownish-orange volcaniclastic overbank clay-, and siltstones and bluish-green overbank sheet sandstone, while the Whitney Member mostly comprises pale-brown 
massive, nodular, eolian siltstones (LaGarry, 1998). The TGP sedimentary succession spans the late Chadronian, Orellan and Whitneyan NALMAs (Prothero and Whittlesey, 1998). The boundaries of these NALMAs do not coincide with those of similarly named lithostratigraphic units, with the Chadronian-Orellan transition defined by the first appearance of the artiodactyls Hypertragulus calcaratus and Leptomeryx evansi ocurring ca. $10 \mathrm{~m}$ below the contact between the Chadron Formation and the Orella Member of the Brule Formation (Zanazzi et al., 2009). The central part of TGP is occupied by a multi-storey complex of Orellan channels, which incised ca. $20 \mathrm{~m}$ into the underlying Chadronian deposits, however the Chadronian-Orellan boundary interval is preserved outside the channel complex. Magnetostratigraphically, the TGP section spans chrons C15r-C12n (Prothero, 1996). Of the seven volcanic tuffs identified so far at TGP, only the Upper and Lower Whitney Ashes have been previously dated using the ${ }^{40} \mathrm{Ar} /{ }^{39} \mathrm{Ar}$ technique, producing recalculated ages of $30.97 \pm 0.36 \mathrm{Ma}$ (biotite) and $32.25 \pm 0.06 \mathrm{Ma}$ (anorthoclase), respectively (Swisher and Prothero, 1990).

\section{$3 \mathrm{U}-\mathrm{Pb}$ zircon dating of volcanic tuffs from the WRG}

We collected 23 volcanic tuff samples from Flagstaff Rim and TGP which are briefly described in the Supplementary Information (Section S1). Of these, 15 samples yielded abundant euhedral zircons of broadly similar morphology, with frequent melt inclusions, and aspect ratios of 5-7. Overall, zircons recovered from the TGP tuffs were slightly smaller (100-200 $\mu \mathrm{m}$ in length) than those from Flagstaff $\operatorname{Rim}(100-400 \mu \mathrm{m})$. A total of 197 single zircons crystals and crystal fragments (6-19 grains/sample) were analysed using CA-ID-TIMS methodologies employed at the Natural Environment Research Council Isotope Geosciences Laboratory (NIGL), British Geological Survey. Details of analytical protocols, along with tabulated results, are included in the Supplementary information (Section S2, Table S2). However, two important points are briefly outlined here: (i) all zircons were chemically abraded (Mattinson, 2005) prior to dissolution in order to minimise the effects of $\mathrm{Pb}$-loss; and (ii) all 
samples were spiked using the gravimetrically calibrated ET535 or ET2535 EARTHTIME U-Pb tracer solutions (Condon et al., 2015; McLean et al., 2015).

Low-precision data characterised by radiogenic to common $\mathrm{Pb}\left(\mathrm{Pb}^{*} / \mathrm{Pb}_{c}\right)$ ratios below $1(\mathrm{n}=18)$ were excluded from further interpretation. Three normally discordant analyses with high radiogenic $\mathrm{Pb}$ content (>25 pg, compared to an average of $7 \mathrm{pg}$ for the rest of the dataset) reflect the presence of older inherited cores. A further five analyses, characterised by $\mathrm{Pb}^{*} / \mathrm{Pb}_{\mathrm{c}}<5$, and thus sensitive to common $\mathrm{Pb}$ correction, gave reversely discordant data which may be attributed to the presence of a second source of common $\mathrm{Pb}$ in addition to laboratory blank, likely in the form of mineral and/or melt inclusions. All discordant analyses were excluded from further interpretation. The analytical precision of the remaining ${ }^{206} \mathrm{~Pb} /{ }^{238} \mathrm{U}$ dates varied between $0.04-0.78 \%(0.02-0.27 \mathrm{Myr})$. Zircon dates from each sample showed significant scatter over 0.4-3.0 Myr, in excess of analytical uncertainty. Potential causes for this scatter include post-depositional $\mathrm{Pb}$-loss, pre-eruptive processes, either through the recycling of older xenocrysts or prolonged crystallization prior to eruption, and post-eruption reworking during transport, sedimentation, and subsequent pedogenesis. ${ }^{206} \mathrm{~Pb} /{ }^{238} \mathrm{U}$ dates from cathodoluminescence imaged zircons (see Supplementary Information, Figure S3.1) suggest that scatter on the order of a few hundred kyr is present even within zircon populations that appear to be free of inherited cores. Part of the observed scatter is likely caused by detrital zircons incorporated during deposition, as most WRG tuffs exhibit root traces on a scale of a few tens of $\mathrm{cm}$, and the background sedimentation of the WRG mostly consists of reworked volcaniclastic material which is fractionally older than the depositional ages.

Due to the issues outlined above, assignment of an 'eruptive age' based upon a spectrum of zircon ${ }^{206} \mathrm{~Pb} /{ }^{238} \mathrm{U}$ dates requires an element of subjective data selection. Typically, coherent populations of youngest dates are combined via a weighted mean calculation to derive an age, however incorporation of dates from material which substantially predates eruption will bias the interpretation towards an older average date. An alternative approach is to make the assumption 
that the youngest date approximates the youngest zircon in the sample, which inferentially should best approximate the timing of eruption. The weakness in this approach is that reproducibility is discounted as means to assess the robustness of the results, which opens up the question of whether the youngest date is representative of a closed-system zircon, or the result of a nonsystematic process (i.e. Pb-loss). Additionally, from an analytical point of view, the youngest analysis would fail to capture the distribution of results that would be expected from a single zircon population crystallizing at the time of eruption. Taking into account the strengths and limitation of both approaches we present multiple interpretations of our dataset (see Supplementary Information Section 3.3) to demonstrate that the choice of interpretive framework does not significantly impact the ages assigned to each sample. Our preference is to calculate weighted mean ages based on a selection of youngest coherent zircon populations from each sample, assumed to represent eruption/deposition age. The selection of representative dates is discussed in the Supplementary Information (Sections S3.1 and S3.2) and was guided by: (i) reproducibility of single zircon ${ }^{206} \mathrm{~Pb} /{ }^{238} \mathrm{U}$ dates (at the $2 \sigma$ level) quantified through the mean square of the weighted deviates (MSWD), and (ii) overall stratigraphic consistency of the dataset. The latter criterion applies in particular to the lower part of the Flagstaff Rim succession, where the age gap between consecutive tuffs is comparable in magnitude to the analytical uncertainty of single-grain analyses. Our preferred interpretation (Table 1, Figure2) is based on considering reproducibility of the single-crystal ${ }^{206} \mathrm{~Pb} /{ }^{238} \mathrm{U}$ dates included in each weighted mean age, while keeping the MSWD within acceptable limits for populations consisting of 3-8 analyses (Wendt and Carl, 1991). Alternative interpretations of the dataset based on fewer of the youngest analyses, or 'youngest date' from each sample are statistically equivalent to our preferred model (see Supplementary Information, section S3.3) and therefore do not significantly impact the derived age models. Inclusion of additional older dates results in weighted mean ages with unacceptably high MSWD, which are considered to have low probability (see Supplementary Information, section S3.3). 


\section{Age-depth modelling}

Age-depth models for the Flagstaff Rim and TGP sedimentary successions (Figure 3 ) were developed using the dataset described above with the Bayesian approach implemented in the P_Sequence routine of the OxCal 4.2 software package (Bronk Ramsey, 2008). Details of the two models and output age-depth data at a resolution of $50 \mathrm{~cm}$ for both the Flagstaff Rim and TGP successions are included in the Supplementary Information (Section S4). The random analytical uncertainties of each weighted mean ${ }^{206} \mathrm{~Pb} /{ }^{238} \mathrm{U}$ date were modelled in OxCal, whereas the correlated systematic uncertainties related to the calibration of the EARTHTIME isotopic tracer $( \pm 0.03 \%)$, and the ${ }^{238} \mathrm{U}$ decay constant ( $\pm 0.11 \%$ ) were added in quadrature to the $95 \%$ uncertainty envelope of both agedepth models. This approach ensures that modelled ages are directly comparable to astronomically tuned or ${ }^{40} \mathrm{Ar} /{ }^{39} \mathrm{Ar}$ dated records.

Due to the nature of fluvial and eolian deposition, both the Flagstaff Rim and the TGP records are likely to contain hiatuses of unknown duration. The impact of such hiatuses on the accuracy of the age-depth models developed in this study is mitigated by three factors: (i) the relatively high stratigraphic resolution of the Flagstaff $\operatorname{Rim}{ }^{206} \mathrm{~Pb} /{ }^{238} \mathrm{U}$ dataset makes the presence of non-identified hiatuses exceeding a few tens of kyr in this record unlikely; (ii) composite measured sections at both localities were constructed so as to avoid recognizable paleo-channel structures and ensure, as far as possible, the completeness of the record, and (iii) a comparison between paleosols from Flagstaff Rim and TGP and modern soils of the same type suggests that hiatuses in excess of a few tens of kyr are unlikely, except for the interval below the TP-2 tuff at TGP, where gaps on the order of $100 \mathrm{kyr}$ may be present (Griffis, 2011; Terry, 2001).

\section{Discussion}


The implications of high-precision ${ }^{206} \mathrm{~Pb} /{ }^{238} \mathrm{U}$ dating of the WRG tuffs for the timing of environmental change recorded in central North America and the chronology of the Chadronian-Whitneyan NALMAs, is discussed below. For clarity we use $t_{z}$ and $t_{m}$ to denote ${ }^{206} \mathrm{~Pb} /{ }^{238} \mathrm{U}$ zircon dates, and data extracted from ${ }^{206} \mathrm{~Pb} /{ }^{238} \mathrm{U}$ calibrated age-depth models respectively.

\subsection{Comparison with published ${ }^{40} \mathrm{Ar} /{ }^{39} \mathrm{Ar}$ geochronology}

Interpreted weighted mean ${ }^{206} \mathrm{~Pb} /{ }^{238} \mathrm{U}$ dates from this study are younger than the biotite and anorthoclase ${ }^{40} \mathrm{Ar} /{ }^{39} \mathrm{Ar}$ dates of Swisher and Prothero (1990) from the same tuffs (Figure 3). While the magnitude of the discrepancy varies depending on the age assigned to the FCs neutron fluence monitor, with published values ranging between $\mathrm{FCs}=27.84-28.29 \mathrm{Ma}$ (Kuiper et al., 2008; Renne et al., 1994; Renne et al., 2010; Renne et al., 1998; Rivera et al., 2011; Wotzlaw et al., 2013), none of the available calibration options result in equivalent ${ }^{40} \mathrm{Ar} /{ }^{39} \mathrm{Ar}$ and ${ }^{206} \mathrm{~Pb} /{ }^{238} \mathrm{U}$ data pairs (see Supplementary Information, Section S5). Interpreting the geochronology of eruptive volcanics in terms of depositional age requires the identification of pre-eruptive bias (e.g. pre-eruptive zircon, extraneous $\mathrm{Ar}$ ), and/or post-depositional modification of the isotope systematics (e.g. $\mathrm{Pb}$ and/or $\mathrm{Ar}$ loss). Additional bias may result from analytical protocols, and the nature of the analysed material, implying that the equivalence of $\mathrm{U}-\mathrm{Pb}$ and ${ }^{40} \mathrm{Ar} /{ }^{39} \mathrm{Ar}$ data pairs cannot always be assumed. The statistical equivalence of biotite and anorthoclase dates from five out of the seven tuffs dated by Swisher and Prothero (1990) would point towards a systematic bias in the ${ }^{40} \mathrm{Ar} /{ }^{39} \mathrm{Ar}$ dataset, however the offset relative to ${ }^{206} \mathrm{~Pb} /{ }^{238} \mathrm{U}$ dates from this study is not constant, and ranges between 0.07-0.96 Myr for FCs=28.201 Ma. The biotite and anorthoclase data underpinning the mean ages of Swisher and Prothero (1990) show scatter of similar magnitude to U-Pb data from this study (0.5-1 Myr), however the precision reported for individual single-crystal step-heating ${ }^{40} \mathrm{Ar} /{ }^{39} \mathrm{Ar}$ measurements is relatively low, at $\pm 100-900 \mathrm{kyr}$ (Prothero and Swisher, 1992). Because the WRG is dominated by reworked volcaniclastic sediments, there is a potential for detrital contamination of 
each tuff during and after deposition, which would be expected to affect $U$ and K-bearing minerals to a similar extent. The implication is that the averaging of low-precision ${ }^{40} \mathrm{Ar} /{ }^{39} \mathrm{Ar}$ datasets could potentially bias mean ages towards older values, while the comparatively higher precision of singlecrystal/fragment ${ }^{206} \mathrm{~Pb} /{ }^{238} \mathrm{U}$ (zircon) dates $( \pm 30-50 \mathrm{kyr}$ ) allows the identification of "youngest" coherent zircon populations assumed to represent eruption age.

Additional sanidine ${ }^{40} \mathrm{Ar} /{ }^{39} \mathrm{Ar}$ dates for the $\mathrm{B}$ and $\mathrm{J}$ tuffs were reported in an abstract by Obradovich et al. (1995). Assuming that these dates were reported relative to a Taylor Creek Rhyolite age of 28.32 Ma, as was done in other papers published by the same author around that time (e.g. Obradovich et al., 1993), and that uncertainties were quoted at the $2 \sigma$ level, calibration relative to an FCs age of 28.201 Ma using the intercalibration factor of Renne et al. (1998), results in a recalculated ${ }^{40} \mathrm{Ar} /{ }^{39} \mathrm{Ar}$ date of $35.65 \pm 0.14 \mathrm{Ma}$ for the $\mathrm{B}$ tuff, statistically equivalent to $t_{z}: 35.81$ $\pm 0.09 \mathrm{Ma}$, while for the J tuff, the recalculated ${ }^{40} \mathrm{Ar} /{ }^{39} \mathrm{Ar}$ age of $34.59 \pm 0.11 \mathrm{Ma}$ is slightly older than $t_{z}: 34.40 \pm 0.05 \mathrm{Ma}$. Other interpretations of the Obradovich et al. (1995) data are discussed in the Supplementary Information, Section S5.

An alternative interpretation of the data, in which post-crystallization open system behaviour would result in anomalously young interpreted ${ }^{206} \mathrm{~Pb} /{ }^{238} \mathrm{U}$ dates, is considered highly unlikely given the use of chemical abrasion protocols and the reproducibility of the multiple analyses $(n=3-8)$ underpinning each weighted mean date. This, in combination with the high stratigraphic resolution of our study and the fact that interpreted ages are consistent with the relative stratigraphic context of the samples at both localities, implies that the ${ }^{206} \mathrm{~Pb} /{ }^{238} \mathrm{U}$ dataset presented here provides a robust calibration of the WRG and its record of environmental change across the EOT.

\subsection{Timing of environmental change in the WRG}

Environmental change in central North America across the EOT is recorded by paleontological, paleobotanical, and lithostratigraphical evidence, as well as high resolution stable isotope proxy 
data. Late Eocene humid woodlands were replaced by more seasonal, semi-arid open habitats in the early Oligocene (Retallack, 1992; Terry, 2001). At the same time, large-shelled land snails, indicative of tropical environments, were replaced by small-shelled drought-tolerant taxa (Evanoff et al., 1992). Aquatic reptiles and amphibians suffered rapid decline, while terrestrial forms remained relatively unaffected (Hutchinson, 1992). The river systems controlling fluvial deposition within the WRG during the Chadronian underwent a gradual transition from meandering and anastomosing geometries to braided channels with high width/depth ratios (Emry, 1992; Evanoff et al., 1992), reflecting an increase in sedimentary load. Subsequently, during the late Chadronian and Orellan, fluvial sedimentation was gradually replaced by eolian deposition (Lukens, 2013; Lukens and Terry, 2014).

At Flagstaff Rim and TGP, the most significant sedimentological change during the Chadronian is a shift from smectite-rich, greenish and bluish-grey, popcorn-textured, hummocky weathering claystones and mudstones to siltier, more resistant, cliff-forming deposits. At Flagstaff Rim, this change occurs as a transitional zone between the B and F-22 tuffs (between 18-56 m in our measured section), placing its age at $t_{m}: 35.8-35.5 \mathrm{Ma}$. At TGP the same transition corresponds to the lithological boundary between the Peanut Peak and Big Cottonwood Creek Members of the Chadron Formation (Terry and LaGarry, 1998), which is situated ca. $5 \mathrm{~m}$ below the TP-1 tuff and is therefore older than $t_{z}: 35.24 \mathrm{Ma}$. Evanoff et al. (1992) reported that a shift from fluvial to eolian deposition occurred at the level of the I tuff at Flagstaff $\operatorname{Rim}\left(t_{m}: \sim 34.6 \mathrm{Ma}\right)$. A similar, gradual transition took place during the deposition of the Orella Member at TGP, beginning at $t_{m}: 33.5 \mathrm{Ma}, 1$ Myr later than in the Flagstaff Rim record (Figure 4), with eolian sedimentation becoming dominant after $t_{m}: 32.8$ Ma during the deposition of the Whitney Member of the Brule Formation (LaGarry, 1998).

Superimposed upon these gradual sedimentological changes, fossil bone and tooth enamel stable isotope records from TGP show pronounced cooling and/or drying expressed as a ca. $1.5 \%$ increase 
in mean $\delta^{18} \mathrm{O}$ values between the Chadronian and Orellan (Zanazzi et al., 2007, 2009; Boardman and Secord, 2013). The higher resolution dataset of the Zanazzi et al $(2007,2009)$ (ca. 6 kyr, compared to ca. $30 \mathrm{kyr}$ in Boardman and Secord, 2013) indicates that the late Chadronian and Orellan were characterized by average $\delta^{18} \mathrm{O}$ values of ca. $22.96 \%$, and $24.12 \%$ respectively. When plotted against our ${ }^{206} \mathrm{~Pb} /{ }^{238} \mathrm{U}$ calibrated age-depth model (Figure 4) the data suggest that the shift from the lower Chadronian to the higher Orellan $\delta^{18} \mathrm{O}$ values occurred in the form of a transitional interval with repeated oscillations of $\pm 1 \%$ between $t_{m}: 33.94-33.70 \mathrm{Ma}$, followed by an interval of elevated $\delta^{18} \mathrm{O}$ values between $t_{m}: 33.70-33.36 \mathrm{Ma}$ (Figure 4).

\subsection{Temporal integration of terrestrial and marine EOT successions}

An assessment of the timing of environmental changes recorded in the WRG relative to the marine record of the greenhouse-icehouse transition requires a direct comparison between our ${ }^{206} \mathrm{~Pb} /{ }^{238} \mathrm{U}$ calibrated age-depth models, and the astronomically tuned marine time scale (Pälike et al., 2006; Westerhold et al., 2014). The accuracy of the timing of the 405 kyr eccentricity cycle which underpins the astronomical tuning of marine EOT records is estimated at ca. $0.1 \%$ during the Eocene/Oligocene (Laskar et al., 2010). However, the accuracy of astronomically tuned time scales further depends on the complete expression and accurate identification of Milankovich cycles in the sedimentary record. Recalculated ${ }^{40} \mathrm{Ar} /{ }^{39} \mathrm{Ar}$ dates from the WRG, demonstrated to be inaccurate in this study, and the astronomical tuning of a sediment core recovered from the vicinity of the Rupelian GSSP at Massignano (van Mourik and Brinkhuis, 2005) have both been used to infer that the ATPS06 may be in error by one 405 kyr eccentricity cycle (Hilgen and Kuiper, 2009). Integrating our ${ }^{206} \mathrm{~Pb} /{ }^{238} \mathrm{U}$ calibrated age-depth models with the published magnetic polarity pattern of the TGP and Flagstaff Rim sections (Prothero and Swisher, 1992; Prothero, 1996) results in an age of $t_{m}: 33.84$ $\pm 0.10 \mathrm{Ma}$ for the Eocene-Oligocene boundary defined at C13r(.14). This age does not support a 405 kyr offset in the calibration of the ATPS06, as it overlaps with astronomically tuned estimates of the 
age of the Eocene-Oligocene boundary, which range between 33.79-33.95 Ma (Brown et al., 2009; Hyland et al., 2009; Jovane et al., 2006; Pälike et al., 2006; Westerhold et al., 2014).

It is important to note that the durations of individual late Eocene magnetochrons within the Flagstaff Rim and TGP records differ significantly from those reported in recent astronomically tuned time scales (Figure 4). Notably chrons C13r (0.72 Myr), and C15r (1.15 Myr) appear to be much shorter, and respectively longer than reported in the ATPSO6 and the recently published Pacific Equatorial Age Transect (PEAT) record (C13r = 1.4-1.3 Myr, C15r = 0.1-0.2 Myr, Pälike et al., 2006; Westerhold et al., 2014). The mutual consistency of the ATPSO6 and PEAT records suggests that the magnetostratigraphy established in the equatorial Pacific paints an accurate picture of the late Eocene-early Oligocene, in terms of both the magnetic polarity pattern, and its numerical age calibration. This in turn indicates that the published late Eocene magnetic polarity pattern of the Flagstaff Rim and/or TGP sections, which deviates from the ATPS06 and PEAT records, may be inaccurate. The implications are that (i) the tuning of the ATPS06 to the 405 kyr eccentricity signal is correct at least as far back as the Eocene-Oligocene boundary, and (ii) a direct comparison between ${ }^{206} \mathrm{~Pb} /{ }^{238} \mathrm{U}$ calibrated age-depth models from this study and marine records calibrated relative to ATPS06 is an appropriate means to quantify the temporal relationship between marine and terrestrial records of environmental change in the earliest Oligocene.

The magnitude of the MAT change associated with the Chadronian-Orellan ( $\left.t_{m}: 33.94-33.70 \mathrm{Ma}\right)$ $\delta^{18} \mathrm{O}$ shift from the TGP record (Zanazzi et al., 2007; Zanazzi et al., 2009) remains controversial, as part of the $\delta^{18} \mathrm{O}$ increase may be attributed to changes in the isotopic composition of precipitation (Sheldon, 2009) and a decrease in the abundance of water-dependent mammals as a result of aridification (Boardman and Secord, 2013). The latter may be related to ocean cooling and Antarctic ice growth, or may represent a long-term aridification trend which progressed gradually from west to east throughout the depositional area of the WRG (Figure 4), possibly as a result of southward advancing uplift in the North American Cordillera (Chamberlain et al., 2012; Mix et al., 2011). 
Nonetheless, the pattern of the TGP $\delta^{18} \mathrm{O}$ shift shows some similarities with the ODP Site 1218 record of Coxall et al. (2005, Figure 4). Although the pattern of the $\delta^{18} \mathrm{O}$ increase at TGP appears more complex than in marine records, with repeated oscillations of $\pm 1 \%$ o between $t_{m}: 33.94-33.70$ Ma, its duration coincides with the interval in which the EOT-1 and Oi-1 events took place at ODP Site 1218 (ca. 33.9-33.6 Ma, Figure 4). Five distinct positive shifts can be identified in the TPG $\delta^{18} \mathrm{O}$ record however a correlation between these and the EOT-1 and Oi-1 events would be tentative at best, given that the total uncertainty of the TGP age-depth model for this interval is on the order of \pm $100-150$ kyr. At TGP, the transitional interval of fluctuating $\delta^{18} \mathrm{O}$ values is followed by a period of elevated $\delta^{18} \mathrm{O}$ values in the early Orellan $\left(t_{m}: 33.60-33.40 \mathrm{Ma}\right)$, which appears to coincide with the early Oligocene glacial maximum (EOGM) reported from ODP Site 1218 between 33.60-33-30 Ma. Consequently, ${ }^{206} \mathrm{~Pb} /{ }^{238} \mathrm{U}$ dating of the TGP record suggests that cooling and/or aridification in central North America across the Chadronian-Orellan boundary was synchronous with the latest Eocene-earliest Oligocene marine $\delta^{18} \mathrm{O}$ shift , rather than predating it as previously indicated by ${ }^{40} \mathrm{Ar} /{ }^{39} \mathrm{Ar}$ data. This brings the North American terrestrial archive of environmental change in line with records from Northern Europe, where a $4-6{ }^{\circ} \mathrm{C}$ drop in MAT across the EOT was inferred from clumped isotope analyses of freshwater gastropod shells from the Hampshire basin (Hren et al., 2013).

\subsection{The age of the Chadronian, Orellan, and Whitneyan NALMAs}

The published biostratigraphy of the Flagstaff Rim and TGP records, combined with the ${ }^{206} \mathrm{~Pb} /{ }^{238} \mathrm{U}$ calibrated age-depth models developed in this study allow for the assessment and comparison of regional biochrons (Figure 5). Although the Chadronian NALMA is represented at both localities the Flagstaff Rim sedimentary succession provides better stratigraphic resolution, owing to significantly higher sediment accumulation rates (ca. $100 \mathrm{~m} / \mathrm{Myr}$, compared to $20-30 \mathrm{~m} / \mathrm{Myr}$ at TGP). At Flagstaff Rim, the top of the early Chadronian, also referred to as the Leptomeryx yoderi Interval Zone, is situated ca. $15 \mathrm{~m}$ below the B tuff (Prothero and Emry, 1996), and is therefore older than $t_{z}: 35.81 \pm$ 
0.09 Ma. At TGP, the last occurrence (LO) of L. yoderi is situated $34 \mathrm{~m}$ below the UPW (Zanazzi et al., 2009) and ca. $1 \mathrm{~m}$ below the TP-1 tuff $\left(t_{z}: 35.21 \pm 0.06 \mathrm{Ma}\right)$. Assuming that there is no significant hiatus within the $1 \mathrm{~m}$ interval below the TP-1 tuff at TGP, the implication is that the highest reported occurrence of $L$. yoderi, and thus the top of the early Chadronian is at least 600 kyr younger in NW Nebraska than in central Wyoming.

The type section of the middle Chadronian, or L. mammifer Interval Zone extends from ca. $15 \mathrm{~m}$ below the B tuff to $15 \mathrm{~m}$ above the $\mathrm{G}$ tuff in the Flagstaff Rim section (Prothero and Emry, 2004), placing the middle/late Chadronian boundary at $t_{m}: 35.12 \pm 0.07 \mathrm{Ma}$. At TGP, Zanazzi et al. (2009) reported the highest occurrence of $L$. mammifer from $18 \pm 2 \mathrm{~m}$ below the UPW, at $t_{m}: 34.43 \pm 0.07$ Ma, 0.7 Myr younger than at the Flagstaff Rim type section.

Prothero and Whittlesey (1998) proposed the first occurrence (FO) of the artiodactyls L. evansi and Hypertragulus calcaratus as a criterion for the identification of the Chadronian-Orellan boundary, replacing the previous definition which relied on the LO of brontotheres (Wood et al., 1941). While the Flagstaff Rim record does not extend beyond the top of the Chadronian (Emry, 1992), at TGP L. evansi and H. calcaratus first appear near the level of the UPW (Zanazzi et al., 2009) placing the Chadronian-Orellan transition at $t_{m}: 34.00 \pm 0.08 \mathrm{Ma}$. At Douglas, in eastern Wyoming the FO of $L$. evansi and $H$. calcaratus has been reported from 5-7 $\mathrm{m}$ above the Persistent White Layer (Prothero and Whittlesey, 1998), a potential equivalent of the UPW, implying a slightly younger age for the base of the Orellan.

Other notable FOs reported by Zanazzi et al. (2009) from the early Orellan at TGP include the oreodont Miniochoerus affinis $\left(t_{m}: 33.68 \pm 0.14 \mathrm{Ma}\right)$ and the rodent Eumys elegans $\left(t_{m}: 33.60 \pm 0.14\right.$ $\mathrm{Ma})$, while the FO of Miniochoerus gracilis $\left(t_{m}: 33.56 \pm 0.12 \mathrm{Ma}\right)$ marks the base of the late Orellan. The earliest Whitneyan fossil assemblages, characterized by the FO of the oreodont Leptauchenia decora have been reported from $44 \mathrm{~m}$ above the UPW at TGP (Prothero, 1982), at $t_{m}: 32.95 \pm 0.33$ Ma. 
The results of our calibration of NALMA index taxa from the WRG suggest diachroneity on the order of 0.7 Myr over a distance of $400 \mathrm{~km}$ in the Chadronian. A 0.7 Myr delay in the demise of index taxa in NW Nebraska, compared to central Wyoming, seems unlikely given the lack of geographic barriers between the two localities. However, apparent diachroneity of mammalian first and last occurrence events, on the order of a few Myr across a single continent, has been demonstrated through multivariate analysis of the North American mammal fossil record, and is thought to arise mainly from under sampling and/or poor sample preservation (Alroy, 1998).

\section{Conclusions}

The application of high-accuracy ${ }^{206} \mathrm{~Pb} /{ }^{238} \mathrm{U}$ (zircon) ID-TIMS geochronology to fifteen volcanic tuffs from the WRG has permitted the construction of a robust age model for the terrestrial EOT (36-31 $\mathrm{Ma}$ ) in North America. This age model provides quantitative information on the sediment accumulation rates and numerical age of two key WRG successions, Flagstaff Rim in Wyoming, and TGP in Nebraska. The U-Pb CA-ID-TIMS based constraints developed in this study are significantly younger than previously published ${ }^{40} \mathrm{Ar} /{ }^{39} \mathrm{Ar}$ dating (Swisher and Prothero, 1990) which, given consideration of the issues surrounding the different datasets, suggests significant inaccuracy in the legacy ${ }^{40} \mathrm{Ar} /{ }^{39} \mathrm{Ar}$ data. We attribute this inaccuracy to the relatively low precision of published ${ }^{40} \mathrm{Ar} /{ }^{39} \mathrm{Ar}$ data, which masks possible contamination with older material during transport, deposition, and subsequent pedogenesis.

Based on our data, environmental change recorded by the WRG across the EOT is the combined result of both global and regional processes acting on different time scales. A Chadronian-Orellan shift from dominantly fluvial to mixed fluvial-eolian deposition progressed gradually from west to east, and was diachronous by as much as 1.5 Myr between central Wyoming and NW Nebraska. Abrupt cooling and/or aridification at the Chadronian-Orellan transition took place over ca. $300 \mathrm{kyr}$. 
Although the complexity of the TGP mammal $\delta^{18} \mathrm{O}$ signal precludes a direct correlation with either the Oi-1 or EOT-1 events, our age models indicate that rapid environmental change in North America coincided with the early Oligocene glaciation of Antarctica, rather than predating it as indicated by published ${ }^{40} \mathrm{Ar} /{ }^{39} \mathrm{Ar}$ data. Crucially, the numerical age calibration of the North American terrestrial

record is underpinned by closely spaced, high-precision ${ }^{206} \mathrm{~Pb} /{ }^{238} \mathrm{U}$ zircon dates from the stratigraphic interval surrounding the EOT. Thus, unlike other terrestrial records of the EOT primarily calibrated through magnetostratigraphy, the chronology of the WRG is independent of the veracity of local magnetic polarity patterns and their correlation to the geomagnetic polarity time scale.

Our study highlights the uncertainties inherent to the numerical age calibration of the stratigraphic record. The first and last occurrence events of Chadronian mammal index taxa from the Flagstaff Rim and TGP sections appear to be diachronous by as much of 0.7 Myr over a relatively short distance of $400 \mathrm{~km}$, probably as a result of undersampling and/or poor sample preservation. The implication is that biostratigraphic events recorded at the Flagstaff Rim and TGP type sections may not be an accurate representation of regional first and last occurrence datums, and therefore the boundaries of the late Eocene-Oligocene NALMAs and their subdivisions cannot, at present, be constrained to better than a few hundred kyr. As a result, the temporal resolution afforded by North American mammal biostratigraphy may be insufficient to accurately constrain the timing of comparatively rapid environmental change, such as that associated with the EOT.

\section{Acknowledgments:}

This work was funded through the European Community's Seventh Framework Programme (FP7/2007-2013) under grant agreement $n^{\circ}$ [215458] and NIGFSC award IP-1228-1110. The authors thank Brent Breithaupt (Bureau of Land Management, Cheyenne, Wyoming), Carla Loop, and Barbara Beasley (Nebraska National Forest, US Forest Service) for providing permits to collect 
samples at Flagstaff Rim and TGP, Joe Hiess, Hemmo Abels and Bill Lukens for assistance during field work, and Blair Schoene and an anonymous reviewer for their thoughtful comments. 


\section{References cited}

Alroy, J., 1998, Diachrony of mammalian appearance events: Implications for biochronology: Geology, v. 26, no. 1, p. 23-26, doi: 10.1130/0091-7613(1998)026<0023:DOMAEI>2.3.CO;2

Boardman, G. S., and Secord, R., 2013, Stable isotope paleoecology of White River ungulates during the Eocene-Oligocene climate transition in northwestern Nebraska: Palaeogeogr. Palaeoclimatol. Palaeoecol., v. 375, p. 38-49, doi: 10.1016/j.palaeo.2013.02.010.

Bronk Ramsey, C., 2008, Deposition models for chronological records: Quat. Sci. Rev., v. 27, p. 42-60, doi: 10.1016/j.quascirev.2007.01.019.

Brown, R. E., Köberl, C., Montanari, A., and Bice, D. M., 2009, Evidence for a change in Milankovitch forcing caused by extraterrestrial events at Massignano, Italy, Eocene-Oligocene boundary GSSP, in Köberl, C., Montanari, A. (eds.), Late Eocene Earth: Hothouse Icehouse and Impacts, Geol. Soc. Am. Special Papers, v. 452, p. 119-137, doi: 10.1130/2009.2452(08).

Chamberlain, C.P., Mix, H.T., Mulch, A., Hren, M.T., Kent-Corson, M.L., Davis, S.J., Horton, T.W., Graham, S.A.. 2012, The Cenozoic climatic and topographic evolution of the western North American Cordillera, Am. J. Sci., v. 312, no. 2, p. 213-262, doi: 10.2475/02.2012.05.

Clark, J., 1975, Controls of sedimentation and provenance of sediments in the Oligocene of the central Rocky Mountains, in Curtis, B. F. (ed.), Cenozoic history of the southern Rocky Mountains, GSA Memoirs, v. 144, p. 97-117, doi: 10.1130/MEM144-p95.

Condon, D. J., Schoene, B., Mclean, N., Bowring, S. A., and Parrish, R., 2015, Metrology and Traceability of U-Pb Isotope Dilution Geochronology (EARTHTIME Tracer Calibration Part I): Geochm. et Cosmochim. Acta, doi: 10.1016/j.gca.2015.05.026.

Coxall, H. K., Wilson, P. A., Pälike, H., Lear, C. H., and Backman, J., 2005, Rapid stepwise onset of Antarctic glaciation and deeper calcite compensation in the Pacific Ocean: Nature, v. 433, no. 7021, p. 53-57, doi: 10.1038/nature03135.

Cramer, B. S., Toggweiler, J. R., Wright, J. D., Katz, M. E., and Miller, K. G., 2009, Ocean overturning since the Late Cretaceous: Inferences from a new benthic foraminiferal isotope compilation:

Paleoceanography, v. 24, p. PA4216, doi: 4210.1029/2008pa001683.

Dupont-Nivet, G., Krijgsman, W., Langereis, C.G., Abels, H.A., Dai, S., Fang, X, 2007, Tibetan plateau aridification liked to global cooling at the Eocene-Oligocene transition, Nature, v. 445, no. 7128, p. 635-638, doi: 10.1038/nature05516.

Emry, R. J., 1973, Stratigraphy and preliminary biostratigraphy of the Flagstaff Rim area, Natrona County, Wyoming: Smithsonian Contributions to Paleobiology, v. 18, pp. 48.

Emry, R. J., 1992, Mammalian range zones in the Chadronian White River Formation at Flagstaff Rim, Wyoming: Princeton Series in Geology and Paleontology, in Prothero, D.R., Berggren, W.A. (eds.), Eocene-Oligocene climatic and biotic evolution, Princeton University Press, p. 106-115, ISBN: 9780691604954. 
Emry, R. J., Russell, L. S., and Bjork, P. R., 1987, The Chadronian, Orellan, and Whitneyan North American land mammal ages, in Woodburne, M. O., ed., Cenozoic Mammals of North America: Geochronology and Biostratigraphy, University of California Press, p. 118-152.

Evanoff, E., Prothero, D. R., and Lander, R. H., 1992, Eocene-Oligocene climatic change in North America: The White River formation near Douglas, east-central Wyoming, in Prothero, D. R., and Berggren, W. A. (eds.), Eocene-Oligocene climatic and biotic evolution, Princeton University Press, $p$. 116-130, ISBN: 9780691604954.

Gradstein, F. M., Ogg, J. G., Schmitz, M. D., and Ogg, G. (eds.), 2012, The Geologic Time Scale 2012, Elsevier, ISBN: 9780444594259.

Griffis, N. P., 2011, Late Eocene terrestrial paleoclimate record from the White River Formation at Flagstaff Rim, Wyoming, USA, MSc Thesis, Temple University, Philadelphia, pp. 65.

Grimes, S. T., Hooker, J. J., Collinson, M. E., and Mattey, D. P., 2005, Summer temperatures of late Eocene to early Oligocene freshwaters: Geology, v. 33, no. 3, p. 189-192, doi: 10.1130/G21019.1.

Hilgen, F. J., and Kuiper, K. F., 2009, A critical evaluation of the numerical age of the EoceneOligocene boundary, in Köberl, C., and Montanari, A. (eds.), Late Eocene Earth: Hothouse Icehouse and Impacts, Geol. Soc. Am. Special Papers, v. 452, pp. 139-148, doi: 10.1130/2009.2452(09).

Hren, M. T., Sheldon, N. D., Grimes, S. T., Collinson, M. E., Hooker, J. J., Bugler, M., and Lohmann, K. C., 2013, Terrestrial cooling in Northern Europe during the Eocene-Oligocene transition: Proc. Nat. Acad. of Sci. USA, v. 110, no. 19, p. 7562-7567, doi: 10.1073/pnas.1210930110.

Hutchinson, J. H., 1992, Western North American reptile and amphibian record across the Eocene/Oligocene boundary and its climatic implications, in Prothero, D. R., and Berggren, A., eds., Eocene-Oligocene climatic and biotic evolution, Princeton University Press, p. 451-463, ISBN: 9780691604954.

Hyland, E., Murphy, B., Varela, P., Marks, K., Colwell, L., Tori, F., Monechi, S., Cleaveland, L., Brinkhuis, H., van Mourik, C. A., Coccioni, R., Bice, D., and Montanari, A., 2009, Integrated stratigraphic and astrochronologic calibration of the Eocene-Oligocene transition in the Monte Cagnero section (northeastern Apennines, Italy): A potential parastratotype for the Massignano global stratotype section and point (GSSP), in Köberl, C., Montanari, A. (eds.), Late Eocene Earth: Hothouse Icehouse and Impacts, Geol. Soc. Am. Special Papers, v. 452, p. 303-322, doi: 10.1130/2009.2452(19).

Ivany, L. C., Van Simaeys, S., Domack, E. W., and Samson, S. D., 2006, Evidence for an earliest Oligocene ice sheet on the Antarctic Peninsula: Geology, v. 34, no. 5, p. 377-380, doi: 10.1130/G22383.1.

Jaffey, A. H., Flynn, K. F., Glendenin, L.E., Bentley, W. C., and Essling, A. M., 1971, Precision measurement of half-lives and specific activities of ${ }^{235} \mathrm{U}$ and ${ }^{238} \mathrm{U}$ : Phys. Rev. C, v. 4, no. 5, p. 18891906, doi: 10.1103/PhysRevC.4.1889. 
Jovane, L., Florindo, F., Sprovieri, M., and Pälike, H., 2006, Astronomic calibration of the late Eocene/early Oligocene Massignano section (central Italy): Geochem. Geophys. Geosyst., v. 7, doi: 10.1029/2005GC001195.

Katz, M.E., Miller, K.G., Wright, J.D., Wade, B.S., Browning, J.V., Cramer, B.S., Rosenthal, Y., 2008, Stepwise transition from the Eocene greenhouse to the Oligocene icehouse, Nat. Geosci., v. 1, no. 5, p. 329-334, doi: 10.1038/ngeo179.

Kohn, M. J., Josef, J. A., Madden, R., Kay, R., Vucetich, G., and Carlini, A. A., 2004, Climate stability across the Eocene-Oligocene transition, southern Argentina: Geology, v. 32, no. 7, p. 621-624, doi: 10.1130/G20442.1.

Kuiper, K. F., Deino, A., Hilgen, F. J., Krijgsman, W., Renne, P. R., and Wijbrans, J. R., 2008, Synchronizing rock clocks of Earth history: Science, v. 320, no. 5875, p. 500-504, doi: 10.1126/science.1154339.

LaGarry, H. E., 1998, Lithostratigraphic revision and redescription of the Brule Formation (White River Group) of northwestern Nebraska, in Terry, D. O., LaGarry, H. E., and Hunt, R. M. (eds.), Depositional Environments, Lithostratigraphy and Biostratigraphy of the White River and Arikaree Groups (Late Eocene to Early Miocene, North America), Geol. Soc. Am. Special Papers, v. 325, p. 6391, doi: 10.1130/0-8137-2325-6.63.

Larson, E. E., and Evanoff, E., 1998, Tephrostratigraphy and source of the tuffs of the White River sequence, in Terry, D.O., LaGarry, H. E., and Hunt, R. M. (eds.), Depositional Environments, Lithostratigraphy, and Biostratigraphy of the White River and Arikaree Groups (Late Eocene to Early Miocene, North America), Geol. Soc. Am. Special Papers, v. 325, p. 1-14, doi: 10.1130/0-8137-23256.1.

Laskar, J., Fienga, A., Gastineau, M., Manche, H., 2011, La2010: a new orbital solution for the longterm motion of the Earth. Astronomy and Astrophysics, v. 532, p. A89, doi: 10.1051/0004$6361 / 201116836$

Ludwig, K., 2003, User's manual for Isoplot 3.75, a geochronological toolkit for Microsoft Excel: Berkeley Geochronology Center Special Publication, v. 5, p. pp. 75.

Mattinson, J. M., 2005, Zircon U-Pb chemical abrasion ("CA-TIMS") method: Combined annealing and multi-step partial dissolution analysis for improved precision and accuracy of zircon ages: Chem. Geol., v. 220, no. 1-2, p. 47-66, doi: 10.1016/j.chemgeo.2005.03.011.

McLean, N., Condon, D. J., Schoene, B., and Bowring, S. A., 2015, Evaluating uncertainties in the calibration of isotopic reference materials and multi-element isotopic tracers (EARTHTIME Tracer Calibration Part II): Geochimica et Cosmochimica Acta, doi: 10.1016/j.gca.2015.02.040.

McLean, N. M., Bowring, J. F., and Bowring, S. A., 2011, An algorithm for U-Pb isotope dilution data reduction and uncertainty propagation: Geochem. Geophys. Geosyst., v. 12, doi:

10.1029/2010GC003478. 
Min, K. W., Mundil, R., Renne, P. R., and Ludwig, K. R., 2000, A test for systematic errors in ${ }^{40} \mathrm{Ar} /{ }^{39} \mathrm{Ar}$ geochronology through comparison with $\mathrm{U} / \mathrm{Pb}$ analysis of a 1.1-Ga rhyolite: Geochim. Cosmochim. Acta, v. 64, no. 1, p. 73-98, doi: 10.1016/S0016-7037(99)00204-5.

Mix, H.T., Mulch, A., Kent-Corson, M.L., Chamberlain, C.P., 2011, Cenozoic migration of topography in the North American Cordillera, Geology, v. 39, no. 1, p. 87-90, doi: 10.1130/G31450.1.

Obradovich, J. D., 1993, A Cretaceous time scale, in Caldwell, W. G. E., and Kauffman, E. G., eds., Evolution of the Western Interior Basin, Geological Association of Canada Special Paper, v. 39, p. 379-396.

Obradovich, J. D., Evanoff, E., and Larson, E. E., 1995, Revised single crystal laser fusion ${ }^{40} \mathrm{Ar} /{ }^{39} \mathrm{Ar}$ ages of Chadronian tuffs in the White River Formation of Wyoming: Geol. Soc. Am. Abstract with Programs, North Central/South Central sections, v. 27, no. 3, p. A77.

Pälike, H., Norris, R. D., Herrle, J. O., Wilson, P. A., Coxall, H. K., Lear, C. H., Shackleton, N. J., Tripati, A. K., and Wade, B. S., 2006, The heartbeat of the Oligocene climate system: Science, v. 314, no. 5807, p. 1894-1898, doi: 10.1126/science.1133822.

Pearson, P. N., McMillan, I. K., Wade, B. S., Dunkley Jones, T., Coxall, H. K., Bown, P. R., and Lear, C. $\mathrm{H} ., 2008$, Extinction and environmental change across the Eocene-Oligocene boundary in Tanzania: Geology, v. 36, no. 2, p. 179-182, doi: 10.1130/G24308A.1.

Prothero, D. R., 1996, Magnetostratigraphy of the White River Group in the High Plains, in Prothero, D. R., and Emry, R. J. (eds.), The Terrestrial Eocene-Oligocene Transition in North America, Cambridge University Press, p. 247-262, ISBN: 9780521021098.

Prothero, D. R., and Emry, R. J., 1996, Summary, in Prothero, D. R., and Emry, R. J. (eds.), The terrestrial Eocene - Oligocene transition in North America, Cambridge University Press, p. 646-664, ISBN: 9780521021098.

Prothero, D. R., and Emry, R. J., 2004, The Chadronian, Orellan, and Whitneyan North American land mammal ages, in Woodburne, M. O., ed., Late Cretaceous and Cenozoic Mammals of North America, Columbia University Press, p. 156-168, ISBN: 9780231130400.

Prothero, D. R., and Swisher, C. C., 1992, Magnetostratigraphy and geochronology of the terrestrial Eocene-Oligocene transition in North America, in Prothero, D. R., and Berggren, W. A. (eds.), EoceneOligocene climatic and biotic evolution, Princeton University Press, p. 49-73, ISBN: 9780691604954.

Prothero, D. R., and Whittlesey, K. E., 1998, Magnetostratigraphy and biostratigraphy of the Orellan and Whitneyan land mammal "ages" in the White River Group, in Terry, D. O., LaGarry, H. E., and Hunt, R. M. (eds)., Depositional Environments, Lithostratigraphy and Biostratigraphy of the White River and Arikaree Groups (Late Eocene to Early Miocene, North America), Geol. Soc. Am. Special Papers, v. 325, p. 39-61, doi: 10.1130/0-8137-2325-6.39.

Renne, P. R., Deino, A. L., Walter, R. C., Turrin, B. D., Swisher , C. C., Becker, T. A., Curtis, G. H., Sharp, W. D., and Jaouni, A.-R., 1994, Intercalibration of astronomical and radioisotopic time: Geology, v. 22, no. 9, p. 783-786, doi: 10.1130/0091-7613(1994)022<0783:IOAART>2.3.CO;2. 
Renne, P. R., Mundil, R., Balco, G., Min, K., and Ludwig, K. R., 2010, Joint determination of ${ }^{40} \mathrm{~K}$ decay constants and ${ }^{40} \mathrm{Ar} * /{ }^{40} \mathrm{~K}$ for the Fish Canyon sanidine standard, and improved accuracy for ${ }^{40} \mathrm{Ar} /{ }^{39} \mathrm{Ar}$ geochronology: Geochim. Cosmochim. Acta, v. 74, p. 5349-5367, doi: 10.1016/j.gca.2010.06.017.

Renne, P. R., Swisher, C. C., Deino, A. L., Karner, D. B., Owens, T. L., and DePaolo, D. J., 1998, Intercalibration of standards, absolute ages and uncertainties in ${ }^{40} \mathrm{Ar} /{ }^{39} \mathrm{Ar}$ dating: Chem. Geol., v. 145, p. 117-152, doi: 10.1016/S0009-2541(97)00159-9.

Retallack, G. J., 1992, Paleosols and changes in climate and vegetation across the Eocene-Oligocene boundary, in Prothero, D. R., and Berggren, W. A. (eds.), Eocene-Oligocene climatic and biotic evolution, Princeton University Press, p. 383-398, ISBN: 9780691604954.

Retallack, G. J., Orr, W. N., Prothero, D. R., Duncan, R. A., Kester, P. R., and Ambers, C. P., 2004, Eocene-Oligocene extinction and paleoclimatic change near Eugene, Oregon: Geol. Soc. Am. Bull., v. 116, no. 7-8, p. 817-839, doi: 10.1130/B25281.1.

Rivera, T. A., Storey, M., Zeeden, C., Hilgen, F. J., and Kuiper, K., 2011, A refined astronomically calibrated ${ }^{40} \mathrm{Ar} /{ }^{39} \mathrm{Ar}$ age for Fish Canyon sanidine: Earth Planet. Sci. Lett., v. 311, p. 420-426, doi: 10.1016/j.epsl.2011.09.017.

Scott, J. W., Sundell, K. A., Thompson, M. D., and Bowring, S. A., 1999, High-precision U-Pb geochronology of Oligocene tuffs from the White River Formation, Douglas, Wyoming: Geol. Soc. Am. Abstracts with Programs, v. 34, p. A15.

Shackleton, N. J., and Kennett, P., 1975, Paleotemperature history of the Cenozoic and the initiation of Antarctic glaciation: oxygen and carbon analyses in DSDP Sites 277, 279, and 281: DSDP Initial Reports, v. 29, p. 743-755, doi: 10.2973/dsdp.proc.29.117.1975.

Sheldon, N.D., 2009, Nonmarine records of climatic change across the Eocene-Oligocene transition, 2009, in Köberl, C., Montanari, A. (eds.), Late Eocene Earth: Hothouse Icehouse and Impacts, Geol. Soc. Am. Special Papers, v. 452, p. 241-248, doi: 10.1130/2009.2452(15).

Stanley, K. O., and Benson, L. V., 1979, Early diagenesis of High Plains Tertiary vitric and arkosic sandstone, Wyoming and Nebraska, in Scholle, P. A., and Schluger, P. R., eds., Aspects of diagenesis: SEPM, Special Publication v. 26, p. 401-423, doi: 10.2110/pec.79.26.

Steiger, R. H., and Jäger, E., 1977, Subcommission on geochronology: Convention on the use of decay constants in geo- and cosmochronology: Earth Planet. Sci. Lett., v. 36, no. 3, p. 359-362, doi: 10.1016/0012-821X(77)90060-7.

Swisher, C. C., and Prothero, D. R., 1990, Single-crystal ${ }^{40} \mathrm{Ar} /{ }^{39} \mathrm{Ar}$ dating of the Eocene-Oligocene transition in North America: Science, v. 249, p. 760-762, doi: 10.1126/science.249.4970.760.

Terry, D. O., 1998, Lithostratigraphic revision and correlation of the lower part of the White River Group: South Dakota to Nebraska, in Terry, D. O., LaGarry, H. E., and Hunt, R. M. (eds.), Depositional Environments, Lithostratigraphy and Biostratigraphy of the White River and Arikaree Groups (Late Eocene to Early Miocene, North America), Geol. Soc. Am. Special Papers, v. 325, p. 15-37, doi: 10.1130/0-8137-2325-6.15. 
Terry, D. O., 2001, Paleopedology of the Chadron Formation of Northwestern Nebraska: implications for paleoclimatic change in the North American midcontinent across the Eocene-Oligocene boundary: Palaeogeogr. Palaeoclimatol. Palaeoecol., v. 168, no. 1-2, p. 1-38, doi: 10.1016/S00310182(00)00248-0.

Terry, D. O., and LaGarry, H. E., 1998, The Big Cottonwood Creek Member: A new member of the Chadron Formation in northwestern Nebraska, in Terry, D. O., LaGarry, H. E., and Hunt, R. M. (eds.), Depositional Environments, Lithostratigraphy and Biostratigraphy of the White River and Arikaree Groups (Late Eocene to Early Miocene, North America), Geol. Soc. Am. Special Papers, v. 325, p. 117-141, doi: 10.1130/0-8137-2325-6.117

van Mourik, C.A., Brinkhuis, H, 2005, The Massignano Eocene-Oligocene golden spike revisited, Stratigraphy, v. 2, no. 1, p. 13-30, doi:

Wade, B.S., Houben, A.J., Quaijtaal, W., Schouten, S., Rosenthal., Y, Miller, K.G., Katz, M.E., Wright, J.D., Brinkhuis, H., 2012, Multiproxy record of abrupt sea-surface cooling across the Eocene-Oligoene transition in the Gulf of Mexico, Geology, v.40, p. 159-162, doi: 10.1130/G32577.1.

Wendt, I., and Carl, C., 1991, The statistical distribution of the mean squared weighted deviation: Chem. Geol., v. 86, no. 4, p. 275-285, doi: 10.1016/0168-9622(91)90010-T.

Westerhold, T., Röhl, U., Pälike, H., Wilkens, R., Wilson, P. A., and Acton, G., 2014, Orbitally tuned time scale and astronomical forcing in the middle Eocene to early Oligocene: Clim. Past, v. 10, p. 955-973, doi:10.5194/cp-10-955-2014.

Wolfe, J. A., 1994, Tertiary climatic changes at middle latitudes of western North America: Palaeogeography. Palaeoclimatol. Palaeoecol., v. 108, no. 3-4, p. 195-205, doi: 10.1016/00310182(94)90233-X.

Wood, H. E., Chaney, R. W., Clark, J., Colbert, E. H., Jepsen, G. L., Reeside, J. B., and Stock, C., 1941, Nomenclature and correlation of the North American continental Tertiary: Geol. Soc. Am. Bull., v. 52, p. 1-48, doi: 10.1130/GSAB-52-1.

Wotzlaw, J.-F., Schaltegger, U., Frick, D. A., Dungan, M. A., Gerdes, A., and Günther, D., 2013, Tracking the evolution of large-volume silicic magma reservoirs from assembly to supereruption: Geology, v. 41, no. 8, p. 867-870, doi: 10.1130/G34366.1.

Xiao, G. Q., Abels, H. A., Yao, Z. Q., Dupont-Nivet, G., and Hilgen, F. J., 2010, Asian aridification linked to the first step of the Eocene-Oligocene climate Transition (EOT) in obliquity-dominated terrestrial records (Xining Basin, China): Clim. Past, v. 6, no. 4, p. 501-513, doi:10.5194/cp-6-501-2010.

Zachos, J.C., Quinn, T.M., Salamy, K.A., 1996, High-resolution ( $10^{4}$ years) deep-sea foraminiferal stable isotope records of the Eocene-Oligocene climate transition, Paleoceanography, v.11, no. 3, p. 251-266, doi: 10.1029/96pa00571.

Zachos, J., Pagani, M., Sloan, L., Thomas, E., and Billups, K., 2001, Trends, rhythms, and aberrations in global climate 65 Ma to present: Science, v. 292, no. 5517, p. 686-693, doi:

10.1126/science.1059412. 
Zanazzi, A., Kohn, M. J., MacFadden, B. J., and Terry, D. O., 2007, Large temperature drop across the Eocene-Oligocene transition in central North America: Nature, v. 445, no. 7128, p. 639-642, doi: 10.1038/nature05551.

Zanazzi, A., Kohn, M. J., and Terry, D. O., 2009, Biostratigraphy and paleoclimatology of the EoceneOligocene boundary section at Toadstool Park, northwestern Nebraska, USA, in Terry, D. O., LaGarry, H. E., and Hunt, R. M. (eds.), Depositional Environments, Lithostratigraphy and Biostratigraphy of the White River and Arikaree Groups (Late Eocene to Early Miocene, North America), Geol. Soc. Am. Special Papers, v. 325, p. 197-214, doi: 10.1130/2009.2452(13).

Zhang, C., and Guo, Z., 2014, Clay mineral changes across the Eocene-Oligocene Transition in the sedimentary sequence at Xining occurred prior to global cooling: Palaeogeogr. Palaeoclimatol. Palaeoecol., v. 411, p. 18-29, doi: 10.1016/j.palaeo.2014.06.031. 
Figure and table captions:

Table 1 Weighted mean ages of dated tuffs from the White River succession. IGSN - International Geo Sample Number www.geosamples.org, MSWD - mean square of the weighted deviates, PoF probability of fit, $n$ - number of grains included in the calculation of the weighted mean date out of the total number of grains analysed (after rejection of analyses with $\mathrm{Pb}^{*} / \mathrm{Pb}_{c}<1$ ). Weighted mean dates and uncertainties were calculated using U-Pb Redux (McLean et al., 2011), and statistical parameters are outputs from Isoplot (Ludwig, 2003). Uncertainties are listed as $\pm X / Y / Z$, where $X$ is the analytical uncertainty, while $Y$ and $Z$ include propagated uncertainties for tracer calibration, and respectively tracer calibration and the ${ }^{238} \mathrm{U}$ decay constant.

Figure 1 Geological setting of sampled volcanic tuffs: A - distribution of the WRG sedimentary succession in central North America and location of the Flagstaff Rim and TGP sections, B lithostratigraphy of the Flagstaff Rim section, showing the stratigraphic position of volcanic tuffs, and the magnetostratigraphy of Prothero and Swisher (1992), C - lithostratigraphy of the TGP section, showing the stratigraphic position of volcanic tuffs and the magnetostratigraphy of Prothero and Swisher (1992). Note that the top of the Peanut Peak Member of the Chadron Formation at TGP is below the stratigraphic column shown here. BCCM - Big Cottonwood Creek Member, UPW - Upper Purplish White Layer, LWA - Lower Whitney Ash, UWA - Upper Whitney Ash. 1 - Age, 2 - NALMA, 3 - lithostratigraphy. Published biotite (Bi), and anorthoclase (An) ${ }^{40} \mathrm{Ar} /{ }^{39} \mathrm{Ar}$ data of Swisher and Prothero (1990) and sanidine (S) data of Obradovich et al. (1995), recalculated using FCs=28.201 Ma (Kuiper et al., 2008) and the ${ }^{40} \mathrm{~K}$ decay constant of Min et al. (2000) are listed in italics.

Figure 2 Summary plot of ranked ${ }^{206} \mathrm{~Pb} /{ }^{238} \mathrm{U}$ dates from volcanic tuff samples collected at Toadstool Geologic Park (A) and Flagstaff Rim (B), based on data from Supplementary Table S2. Data with $\mathrm{Pb} * / \mathrm{Pb}_{\mathrm{c}}$ ratios below 1 were not plotted. The weighted mean ${ }^{206} \mathrm{~Pb} /{ }^{238} \mathrm{U}$ age of each tuff is listed along with its analytical uncertainty.

Figure 3 Plot of U-Pb zircon calibrated time against stratigraphic position/thickness showing the dated tuffs and the age-depth model developed from these data. Uncertainty envelope represents $95 \%$ confidence interval. The input parameters of the model included the positions of lithological boundaries, which are expected to correspond to changes in sedimentation rate, and are represented here as changes in the colour of the uncertainty envelope. These correspond to the boundaries between the Chadron and Brule Formations, and the Orella and Whitney Members of the Brule Formation respectively at TGP, and a fluvial-eolian transition occurring around the level of the I tuff at Flagstaff Rim. Published ${ }^{40} \mathrm{Ar} /{ }^{39} \mathrm{Ar}$ dates (Swisher and Prothero, 1990; Obradovich et al., 1995) calibrated relative to $F C s=28.201 \mathrm{Ma}$ are plotted for comparison. Note that the scales of the two stratigraphic sections are different.

Figure 4 Temporal integration of the marine $\delta^{18} \mathrm{O}$ record of the EOT (Coxall et al., 2005), calibrated relative to ATPS06, and environmental change recorded within the WRG in Wyoming and Nebraska (Zanazzi et al., 2007,2009), calibrated relative to published ${ }^{40} \mathrm{Ar} /{ }^{39} \mathrm{Ar}$ volcanic tuff dates, and ${ }^{206} \mathrm{~Pb} /{ }^{238} \mathrm{U}$ data from this study. Open (closed) diamonds represent U-Pb dated tuffs from Toadstool Geologic Park (Flagstaff Rim). All $\delta^{18} \mathrm{O}$ data plotted as 5-point moving averages. Composite magnetic polarity pattern of the Flagstaff Rim and TGP records is based on Prothero and Swisher (1992), and Prothero (1996). EOT-1 and Oi-1 correspond to the first and second step of the positive $\delta^{18} \mathrm{O}$ shift that characterizes the marine record of the EOT. EOGM - Eocene-Oligocene glacial maximum, 16.1 magnetochron C16n.1n. Note that the plot of the TGP record only extends back to ca. $35.5 \mathrm{Ma}$, or just below the base of the Big Cottonwood Creek Member of the Chadron Formation, as no magnetostratigraphic or radio-isotopic data is available from the underlying Peanut Peak Member. 
Figure 5 Temporal range of key NALMA index taxa from Flagstaff Rim and TGP. A - Dated tuffs plotted against time; B - distribution of index taxa based on published biostratigraphy (Prothero and Emry, 1996, 2004; Prothero and Whittlesey, 1998; Zanazzi et al., 2009) and the stratigraphic age model based on ${ }^{206} \mathrm{~Pb} /{ }^{238} \mathrm{U}$ dates tuffs; C - NALMA

\begin{tabular}{|c|c|c|c|c|c|c|}
\hline Sample & IGSN & $\begin{array}{l}\text { Weighted mean } \\
{ }^{206} \mathrm{~Pb} /{ }^{238} \mathrm{U} \text { date }\end{array}$ & Uncertainty $(2 \sigma)$ & MSWD & PoF & $\mathrm{n}$ \\
\hline$B$ & IEDS10001 & 35.805 & $\pm 0.076 / 0.080 / 0.089$ & 0.93 & 0.39 & 3 of 11 \\
\hline$B+15$ & IEDS10002 & 35.750 & $\pm 0.016 / 0.023 / 0.044$ & 0.49 & 0.74 & 5 of 11 \\
\hline $\mathrm{B}+18$ & IEDS10003 & 35.678 & $\pm 0.019 / 0.025 / 0.046$ & 0.63 & 0.64 & 5 of 9 \\
\hline F-7.5 & IEDS10004 & 35.416 & $\pm 0.019 / 0.025 / 0.045$ & 0.60 & 0.66 & 5 of 7 \\
\hline $\mathrm{F}$ & IEDS10005 & 35.334 & $\pm 0.021 / 0.026 / 0.046$ & 0.19 & 0.94 & 5 of 13 \\
\hline G & IEDS10006 & 35.250 & $\pm 0.020 / 0.026 / 0.046$ & 0.83 & 0.55 & 7 of 14 \\
\hline $\mathrm{H}$ & IEDS10008 & 34.742 & $\pm 0.019 / 0.025 / 0.045$ & 1.51 & 0.17 & 7 of 13 \\
\hline $\mathrm{J}-1$ & IEDS10009 & 34.394 & $\pm 0.018 / 0.024 / 0.044$ & 1.80 & 0.08 & 8 of 9 \\
\hline J & IEDS1000A & 34.398 & $\pm 0.022 / 0.027 / 0.046$ & 1.40 & 0.23 & 5 of 19 \\
\hline TP-1 & IEDS1000B & 35.224 & $\pm 0.038 / 0.043 / 0.057$ & 1.39 & 0.23 & 5 of 11 \\
\hline TP-2 & IEDS1000C & 34.478 & $\pm 0.021 / 0.026 / 0.045$ & 1.38 & 0.23 & 6 of 9 \\
\hline UPW & IEDS1000D & 33.939 & $\pm 0.033 / 0.039 / 0.053$ & 0.90 & 0.51 & 8 of 9 \\
\hline SDP & IEDS1000F & 33.414 & $\pm 0.035 / 0.038 / 0.052$ & 1.50 & - & 2 of 16 \\
\hline LWA & IEDS1000G & 31.777 & $\pm 0.012 / 0.018 / 0.039$ & 1.71 & 0.16 & 10 of 13 \\
\hline UWA & IEDS1000H & 30.908 & $\pm 0.021 / 0.025 / 0.041$ & 1.50 & 0.20 & 5 of 12 \\
\hline
\end{tabular}


A: Map of sampled localities

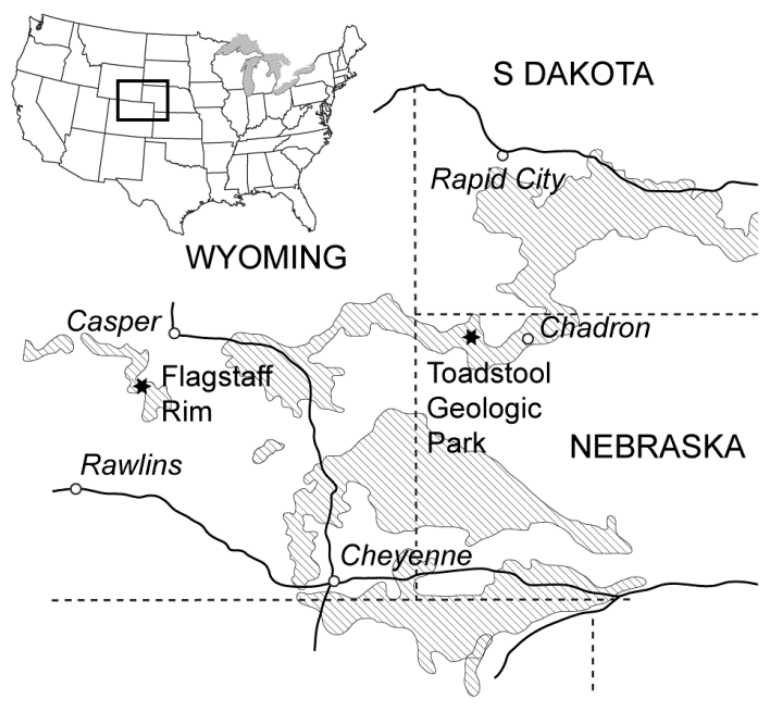

C: Toadstool Geologic Park

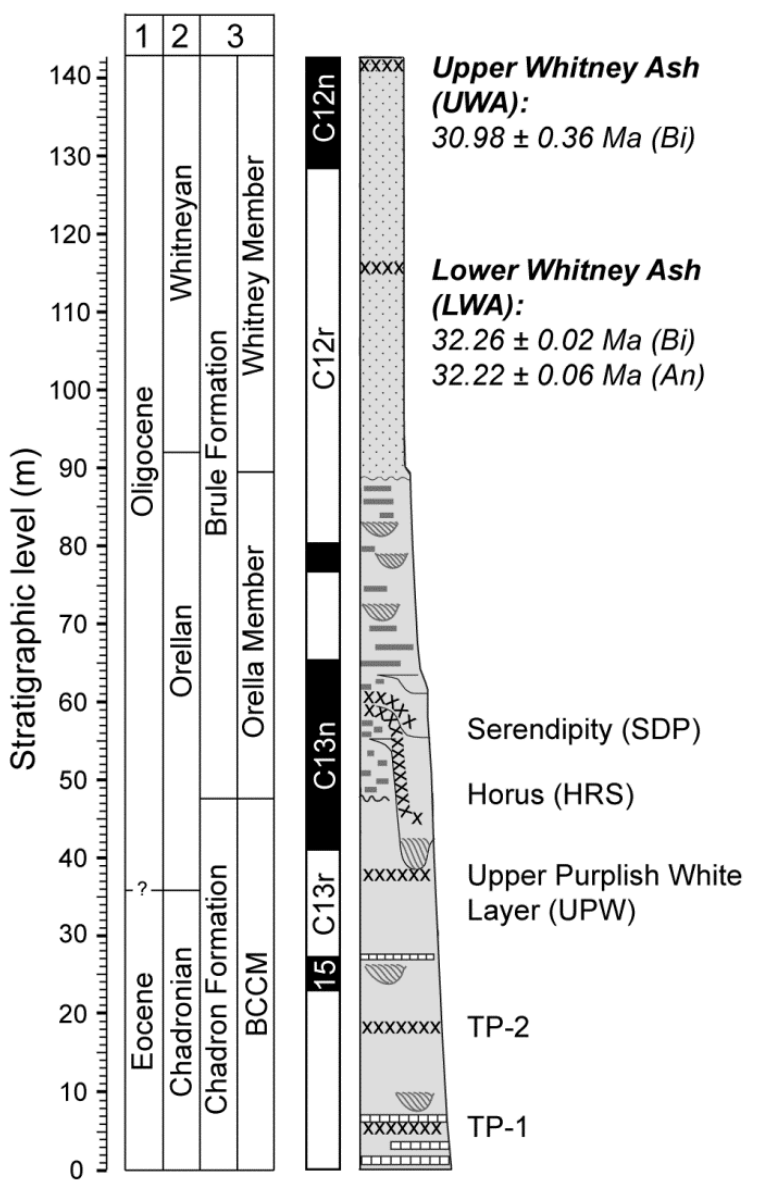

B: Flagstaff Rim

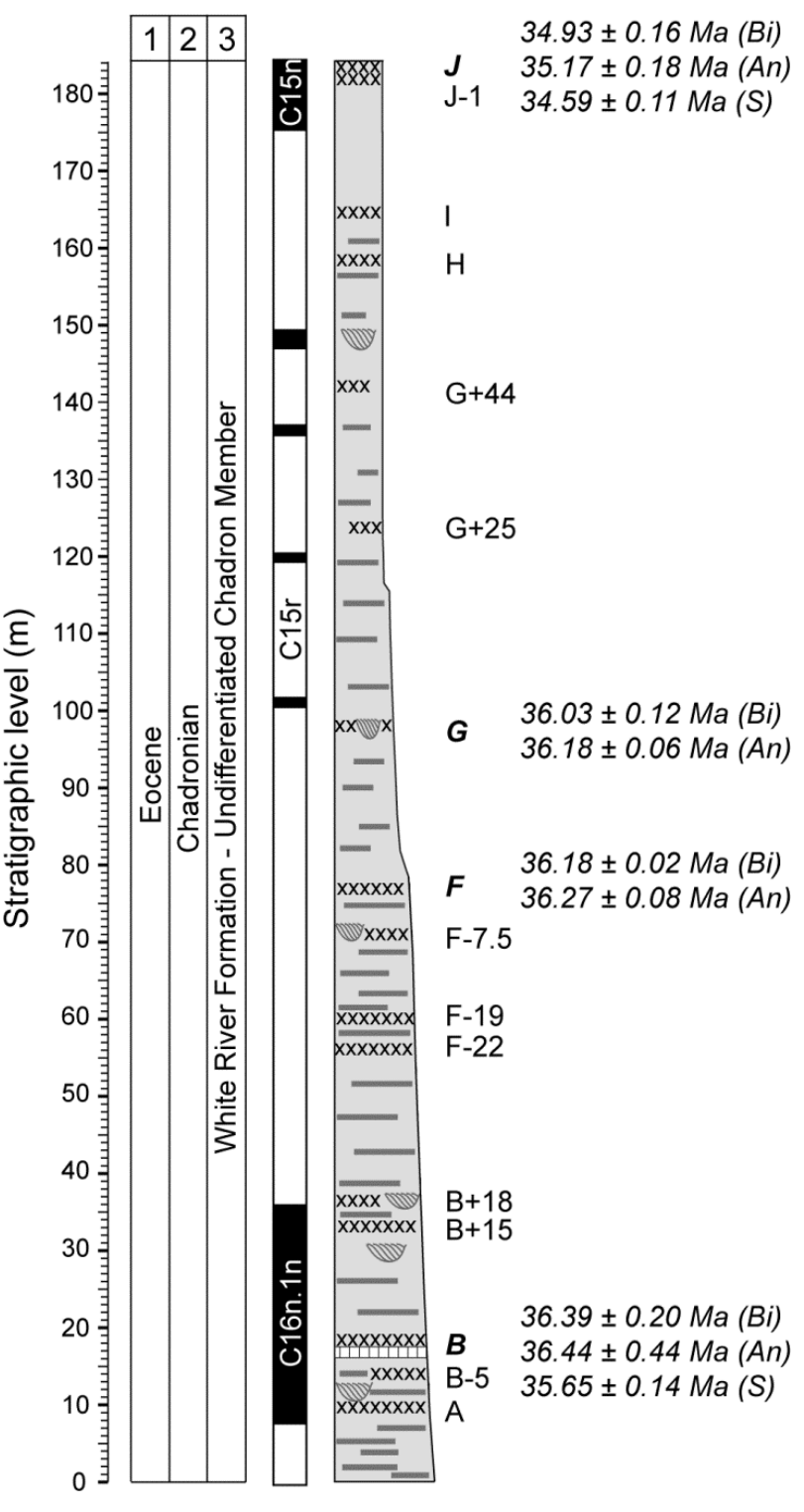




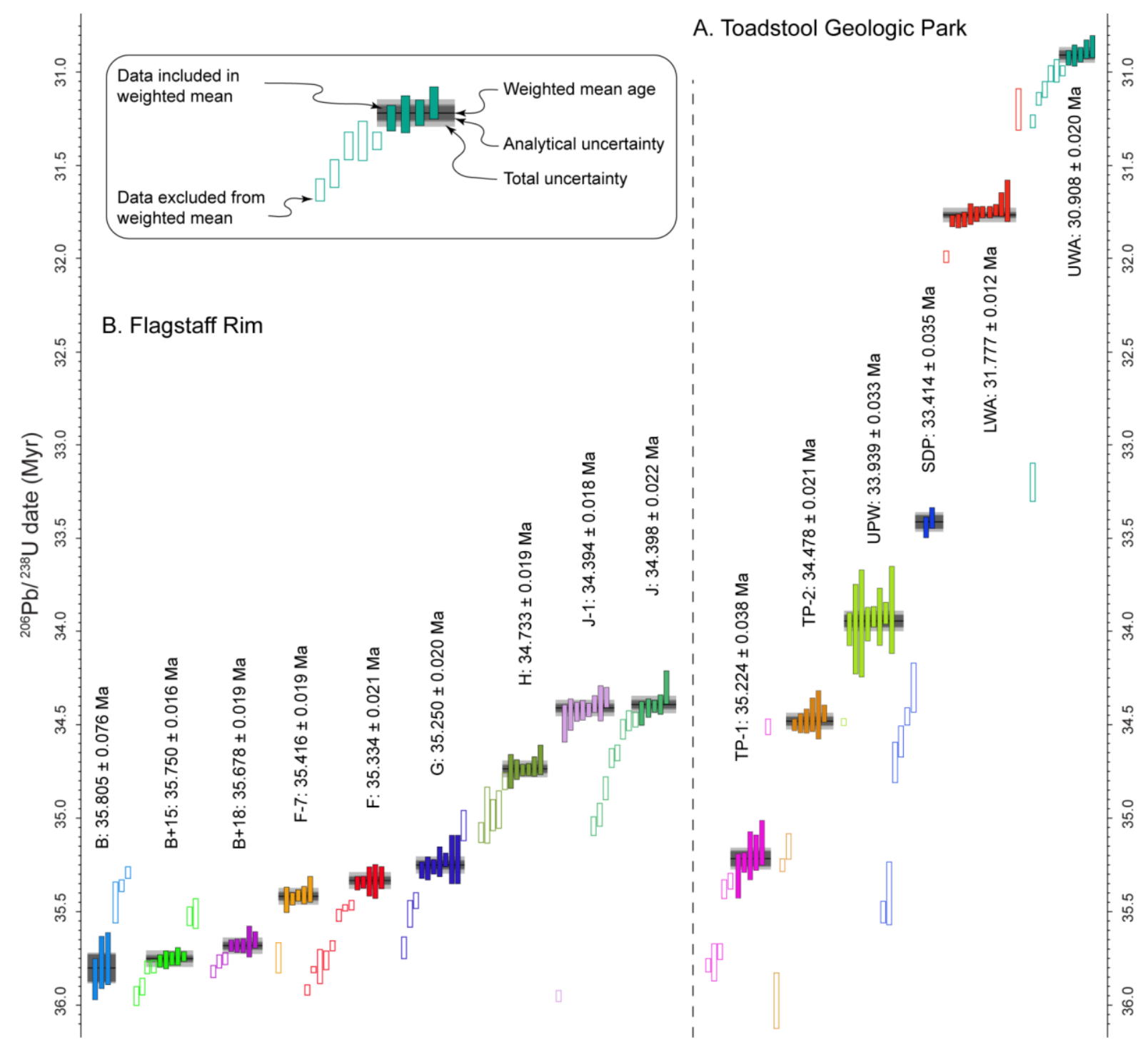




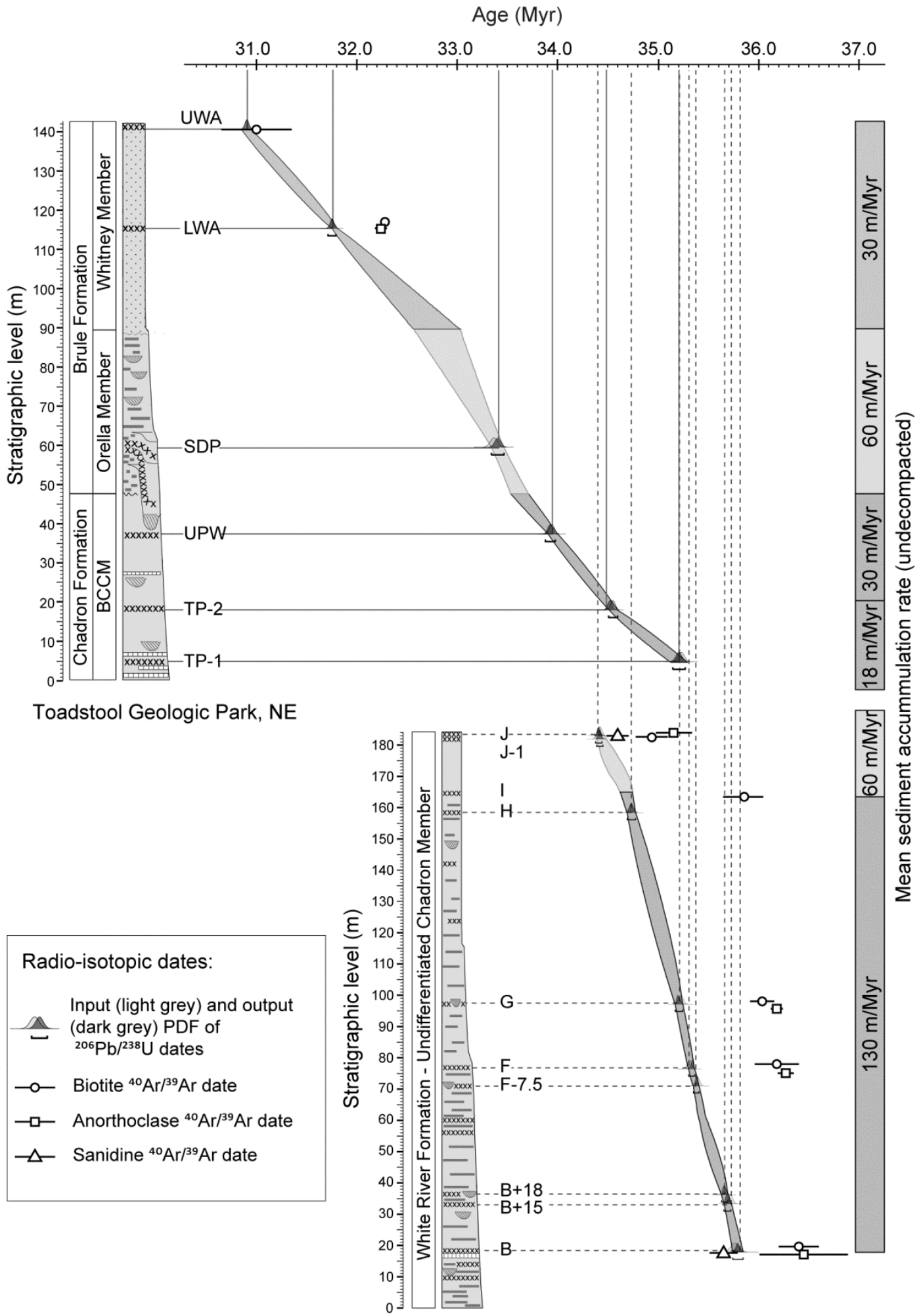

Flagstaff Rim, WY 


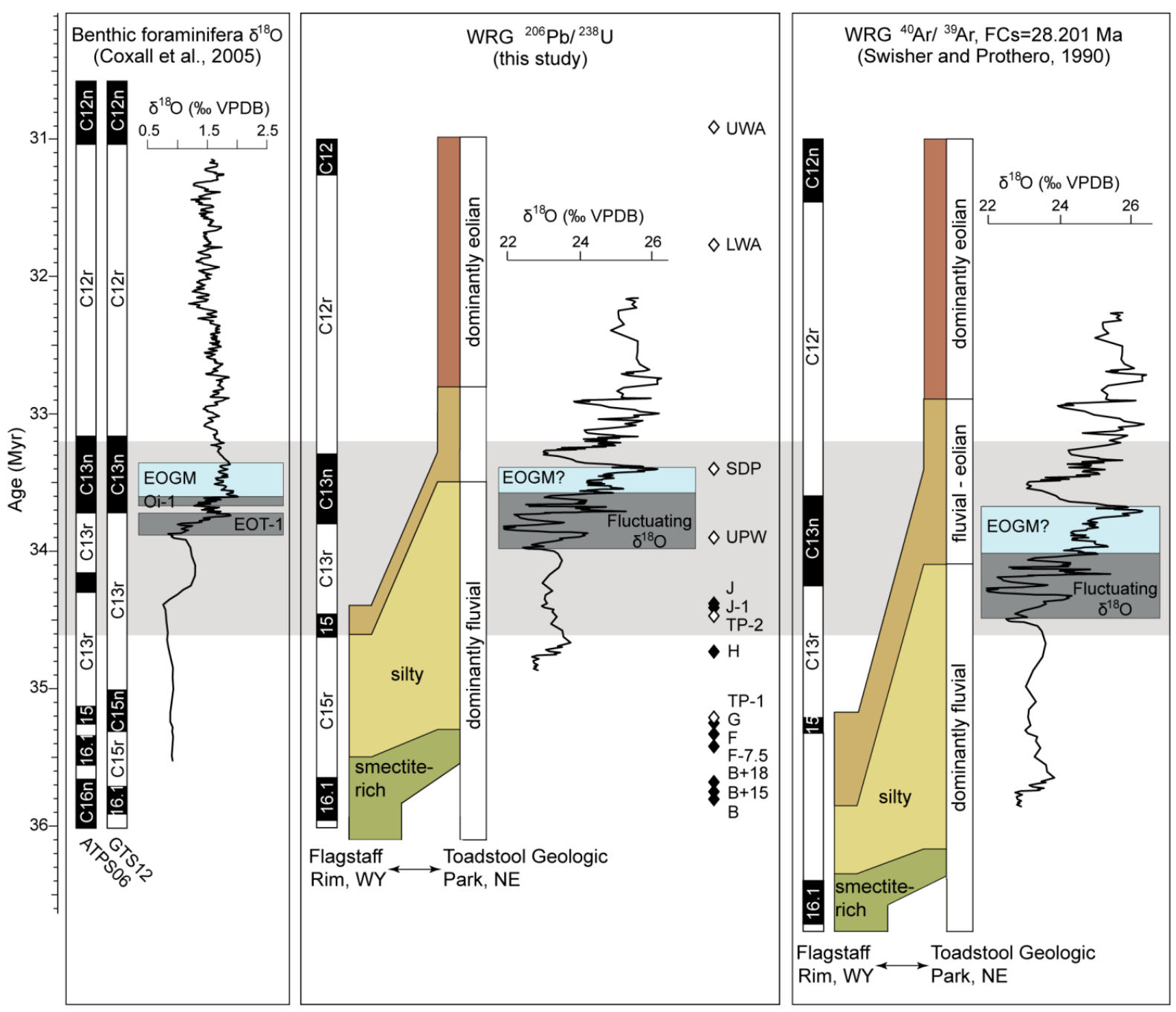




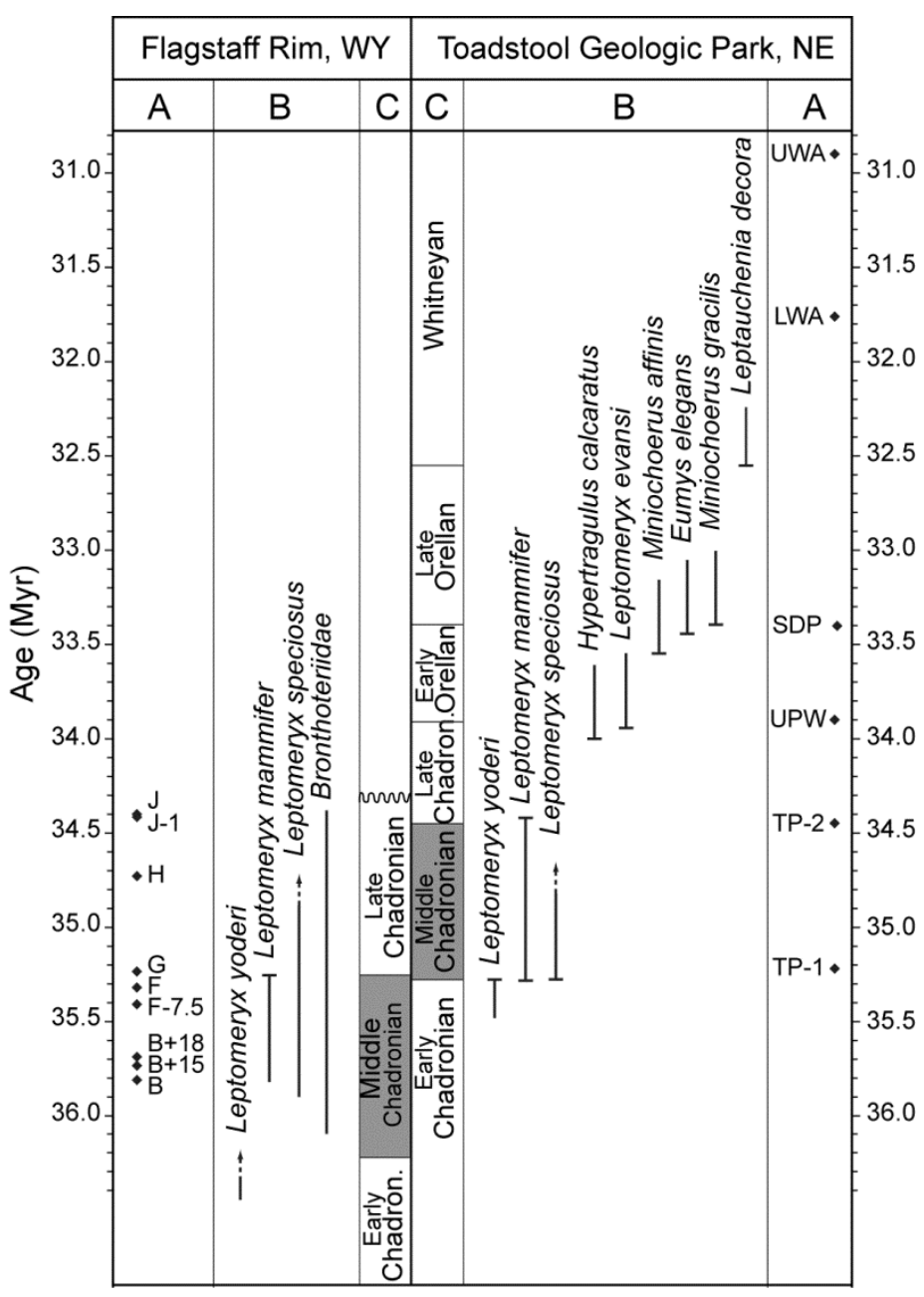

